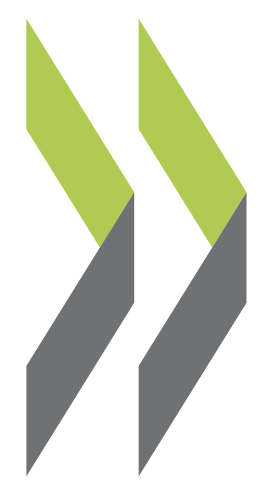

OECD Economics Department Working Papers No. 1105

\title{
Dividing the Pie in Brazil: Income Distribution, Social Policies and the New Middle Class
} Jens Matthias Arnold, João Jalles 
Organisation de Coopération et de Développement Économiques

Organisation for Economic Co-operation and Development

09-Jan-2014

ECONOMICS DEPARTMENT

English - Or. English

DIVIDING THE PIE IN BRAZIL: INCOME DISTRIBUTION, SOCIAL POLICIES AND

THE NEW MIDDLE CLASS

ECONOMICS DEPARTMENT WORKING PAPERS No. 1105

By Jens M. Arnold and João Jalles

All Economics Department Working Papers are available through OECD's Internet website at www.oecd.org/eco/Workingpapers.

JT03350937

Complete document available on OLIS in its original format

This document and any map included herein are without prejudice to the status of or sovereignty over any territory, to the delimitation of international frontiers and boundaries and to the name of any territory, city or area. 


\section{ABSTRACT/RÉSUMÉ \\ Dividing the pie in Brazil: income distribution, social policies and the new middle class}

Brazil has made remarkable progress in reducing poverty and inequality. This reduction is explained by strong growth but also by effective social policies. Besides growth, public services and cash transfers have played the biggest role, the latter notably through the successful "Bolsa Familia" programme. Among public services, improved access to education has played a major role, allowing more Brazilians to move into better-paid jobs. However, shortages in physical school infrastructure are limiting the hours of instruction that students receive. The high drop-out rate needs to be reduced through early interventions such as expanding early-childhood education, by reducing grade-repetition and through more tailored support for those at risk. The quality of teaching could also be raised through more in-service teacher training and stronger performance incentives for teachers. Performance of public services devoted to health and transports has been mixed. Public health services are widely available but suffer from underfunding and training places for medical staff need to be expanded. The public urban transport system suffers from a shortage of investment which is urgently needed to upgrade capacity. Regarding cash transfers, the success of "Bolsa Familia" and new programmes put in place under the umbrella of the "Brasil sem Miseria" programme is remarkable but transfer payments remain too heavily focused on pension benefits. Giving more priority to "Bolsa Familia" and "Brasil sem Miseria" while limiting the real growth of pension expenditures in the future would improve the effectiveness of social expenditures for reducing poverty and inequality.

This Working Paper relates to the 2013 OECD Economic Survey of Brazil (www.oecd.org/eco/surveys/brazil).

JEL classification: D3, H2, H4, I1, I2, I3, J3

Keywords: Distribution, Education, Health, Transfers, Pensions, Wages, Tax

\section{Partager la richesse nationale au Brésil: la distribution des revenus, les politiques sociales et la nouvelle classe moyenne}

Le Brésil a accompli des progrès remarquables en termes de réduction de la pauvreté et des inégalités. Cela tient au dynamisme de la croissance mais aussi à l'efficacité des politiques sociales. En dehors de la croissance, ce sont les services publics et les transferts monétaires qui ont été les facteurs les plus importants, notamment les seconds dans le cadre du programme Bolsa Familia, qui a été couronné de succès. S'agissant des services publics, l'amélioration de l'accès à l'éducation a joué un rôle majeur, en permettant à davantage de Brésiliens d'obtenir des emplois mieux payés. Néanmoins, les problèmes de pénurie d'infrastructures scolaires limitent le nombre d'heures d'enseignement dont bénéficient les élèves. Il faut abaisser les taux élevés d'abandon des études par le biais d'interventions précoces consistant par exemple à développer l'éducation préscolaire, ainsi qu'en réduisant les taux de redoublement et en apportant un soutien plus individualisé aux élèves à risque. On pourrait également rehausser la qualité de l'enseignement en développant la formation en cours d'emploi des enseignants et en renforçant les mesures d'incitation qui récompensent leurs bons résultats. Le bilan des services publics est mitigé dans les domaines de la santé et des transports. Les services de santé publique sont largement accessibles mais ils pâtissent d'un financement insuffisant, et le nombre de places offertes pour la formation du personnel médical doit être accru. Le système public de transports urbains souffre d'un manque d'investissements, alors qu'il est urgent de consacrer des ressources à la modernisation des capacités. S'agissant des transferts monétaires, la réussite de Bolsa Familia et des nouveaux dispositifs mis en place dans le cadre global du programme Brasil sem Miseria est remarquable, mais les prestations de retraite représentent toujours une proportion excessive des transferts sociaux. En accordant une plus grande importance au programme Brasil sem Miseria en général et à Bolsa Familia en particulier, tout en limitant la croissance réelle des dépenses de retraite à l'avenir, les autorités renforceraient l'efficacité des dépenses sociales en termes de réduction de la pauvreté et des inégalités.

Ce Document de travail se rapporte à l'Étude économique de l'OCDE du Brésil, 2013 (www.oecd.org/eco/etudes/bresil).

Classification JEL : D3, H2, H4, I1, I2, I3, J3

Mots clefs : Distribution des revenus, Education, Santé, Transfers, Pensions, Salaires, Impôts

(C) OECD (2014)

You can copy, download or print OECD content for your own use, and you can include excerpts from OECD publications, databases and multimedia products in your own documents, presentations, blogs, websites and teaching materials, provided that suitable acknowledgment of OECD as source and copyright owner is given. All requests for commercial use and translation rights should be submitted torights@oecd.org. 


\section{TABLE OF CONTENTS}

Dividing the pie in Brazil: income distribution, social policies and the new middle class............................ 5

Poverty and inequality have been improving substantially but inequality remains high .......................... 5

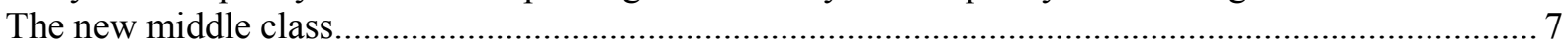

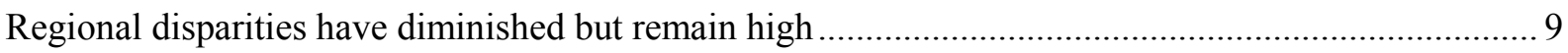

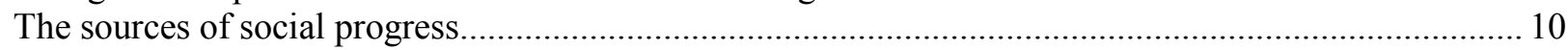

Deliberate policies to improve income distribution have contributed significantly to social progress . 10

Education and labour market policies have improved the distribution of labour incomes .................... 11

Social transfer programmes have played an important role............................................................... 14

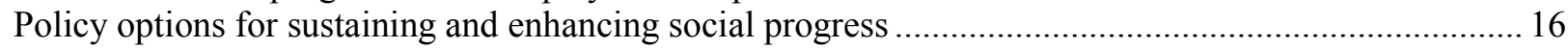

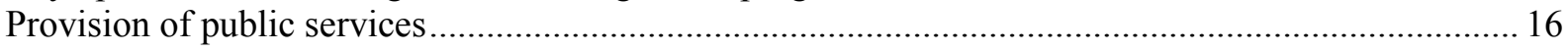

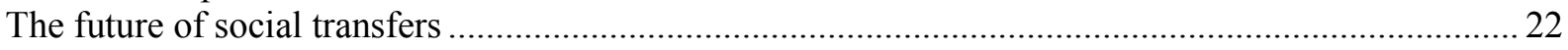

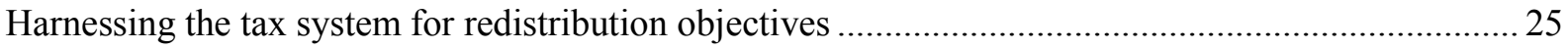

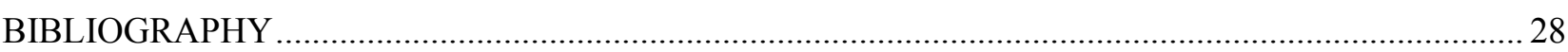

\section{Tables}

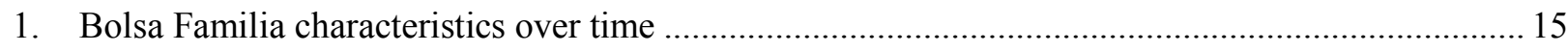

\section{Figures}

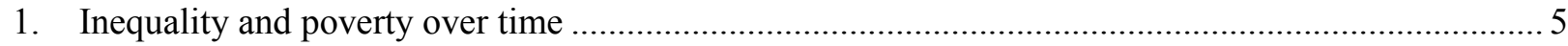

2. Average annual real income growth $2003-11$ by deciles ............................................................... 6

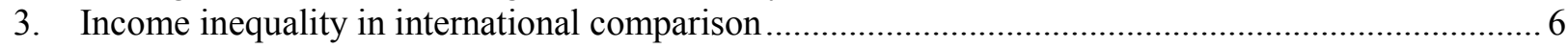

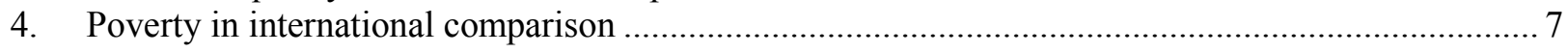

5. Distribution of population by economic classes in Brazil (in millions) ........................................... 7

6. A comparison of growth and size of the middle class in Latin America ............................................. 8

7. Characteristics of people who joined the middle class.................................................................... 9

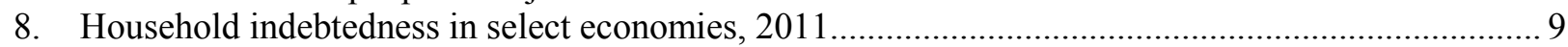

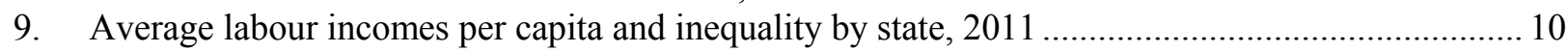

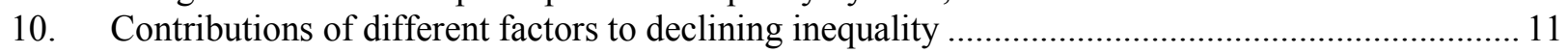

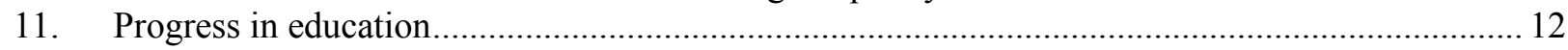

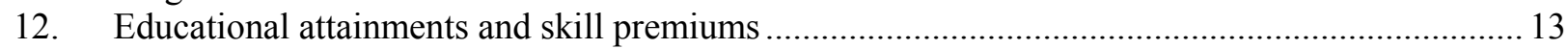

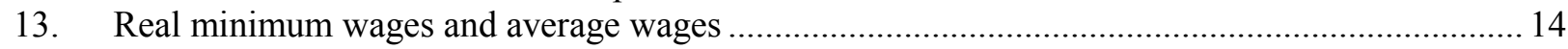

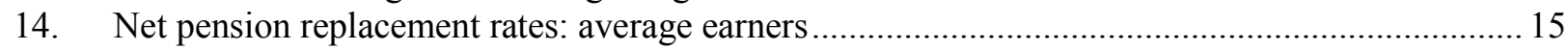

15. Share of population deprived of access to basic goods and services......................................... 17

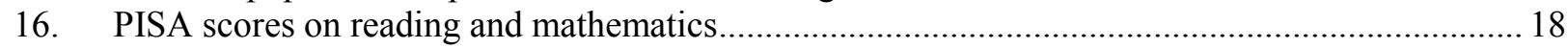

17. Enrolment rates at age 4 in early childhood and primary education (2005 and 2010) .................20

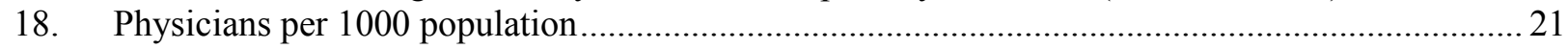

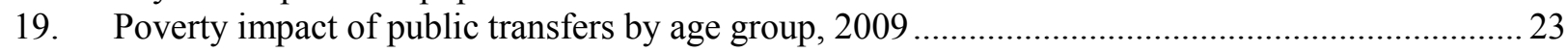

20. Reduction of inequality through taxes and transfers ...............................................................2 25

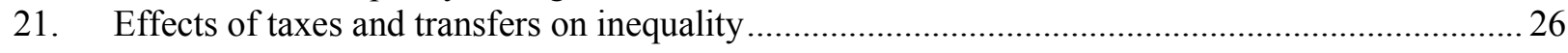

\section{Boxes}

1. Summary of recommendations:

The statistical data for Israel are supplied by and under the responsibility of the relevant Israeli authorities. The use of such data by the OECD is without prejudice to the status of the Golan Heights, East Jerusalem and Israeli settlements in the West Bank under the terms of international law. 
ECO/WKP(2014)1 


\title{
Dividing the pie in Brazil: income distribution, social policies and the new middle class
}

\author{
By \\ Jens M. Arnold and João Jalles ${ }^{1}$
}

\section{Poverty and inequality have been improving substantially but inequality remains high}

A distinct feature of Brazil's economic progress since the macroeconomic stabilisation in the 1990s is its social dimension. Income inequality, which has been relatively high, has been on a steady downward trend since the late 1990s, as evidenced by the decline of a common measure of inequality, the Gini coefficient (Figure 1). Between 1997 and 2011, inequality of disposable income has fallen by over 12\%, and it is currently at its lowest level since data became available in 1960. These dynamics are particularly impressive in international context since two thirds of the countries in the world experienced an increase in income inequality despite solid growth between 1990 and 2005 (United Nations, 2012, OECD, 2011d). Most of the reduction in inequality results from income gains of Brazil's poorest.

Figure 1. Inequality and poverty over time

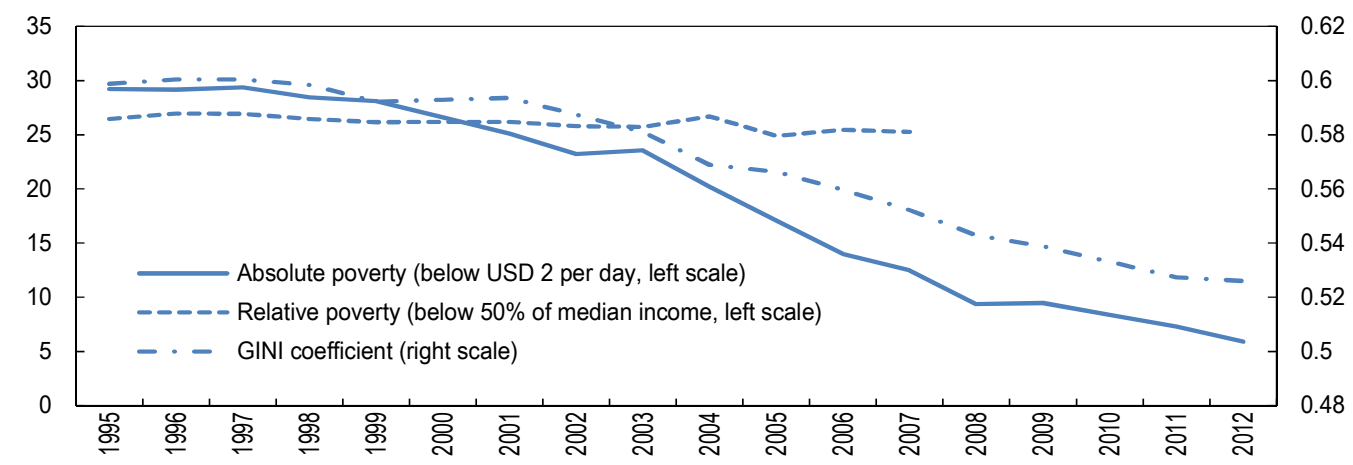

How to read this chart: Absolute poverty headcount refers to per cent of the population with household income per capita below the extreme poverty line set out in the Millennium Development Goals of the United Nations (USD 2 per day). Relative poverty is the per cent of the population with per capita income below $50 \%$ of the median income. The Gini coefficient measures the inequality of distribution on a scale between 0 and 1 with higher values representing more income inequality.

Source: IPEA.

Poverty rates have fallen visibly, in particular since 2003, regardless of the exact definition of the poverty line employed. Using the extreme poverty definition of the United Nations, the percentage of the population living below USD 2 per day dropped from 23.2\% to 5.9\% between 2002 and 2012 (Figure 1). As a result, Brazil reached the Millennium Development Goal (MDG) of reducing extreme poverty by 2015 to one quarter of its 1990 level in 2007, eight years ahead of schedule. Incomes have grown visibly

1. A version of this paper originally appeared as Chapter 2 in the OECD Economic Survey of Brazil 2013, published in October 2013 under the authority of the Economic and Development Review Committee. Jens Arnold is Head of the Brazil/Portugal Desk at the OECD Economics Department, João Jalles is Economist on the Desk. The authors are grateful to Pierre Beynet, Stijn Broecke, Christian Daude, Andrew Dean, Luiz de Mello, Robert Ford, Horacio Levy, Yuki Murakami, Marcelo Neri, Ricardo Paes de Barros, Michael Schoenstein, Richard Yelland, Felix Zimmerman and several Brazilian government officials for valuable discussions, comments and suggestions on earlier drafts. Special thanks go to Anne Legendre for statistical assistance and Sylvie Ricordeau for editorial assistance. 
stronger for lower income strata than for Brazil's affluent population over the last years, with incomes of the poorest decile growing 3 times faster than for the most affluent decile (Figure 2).

Figure 2. Average annual real income growth 2003-11 by deciles

In percent

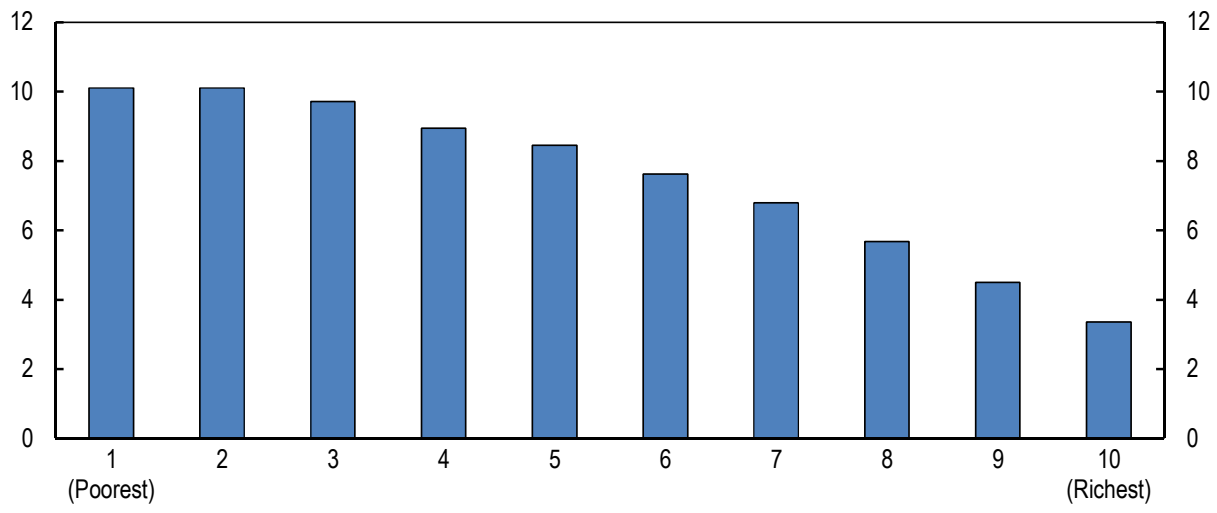

Source: IPEA (2012).

But despite this progress, much remains to be done. Brazil still has one of the highest inequality levels in the world (Figure 3) and it would take at least 20 years at the current pace to reach the inequality levels of the United States, which is one of the most unequal OECD economies (Lopez-Calva and Lustig, 2010). While Latin America is itself a region that is generally characterised by high levels of inequality, Brazil has one of the highest inequality levels even among its regional peers. The last decade, however, has seen Brazil converging towards the regional average, with inequality declining almost twice as fast as in the regional average (Lopez Calva et al., 2011; Bianchi et al., 2012). Poverty is still higher than in some Latin American countries, but significantly lower than in a number of Asian countries (Figure 4).

\section{Figure 3. Income inequality in international comparison}

Gini coefficient, last available year

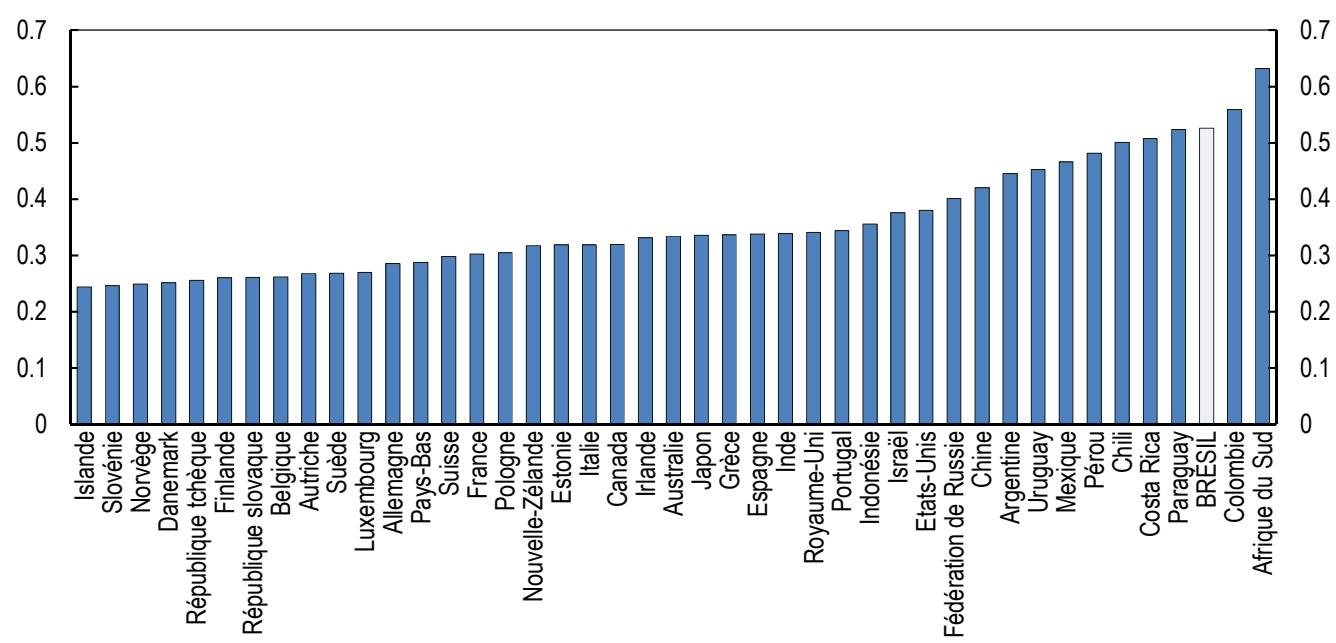

Note: The last available year is 2010 for most countries, 2012 for Brazil.

Source: OECD inequality database except for Non-OECD countries for which the source is World Bank (2013): Argentina, Brazil, China, Colombia, Costa Rica, Indonesia, India, Paraguay, Peru, Russian Federation, South Africa, Uruguay. The last available year is 2010 for most countries. For Brazil, the source is IPEA (2013). 
Figure 4. Poverty in international comparison

Per cent of the population with per capita income below USD 2 a day, last available year

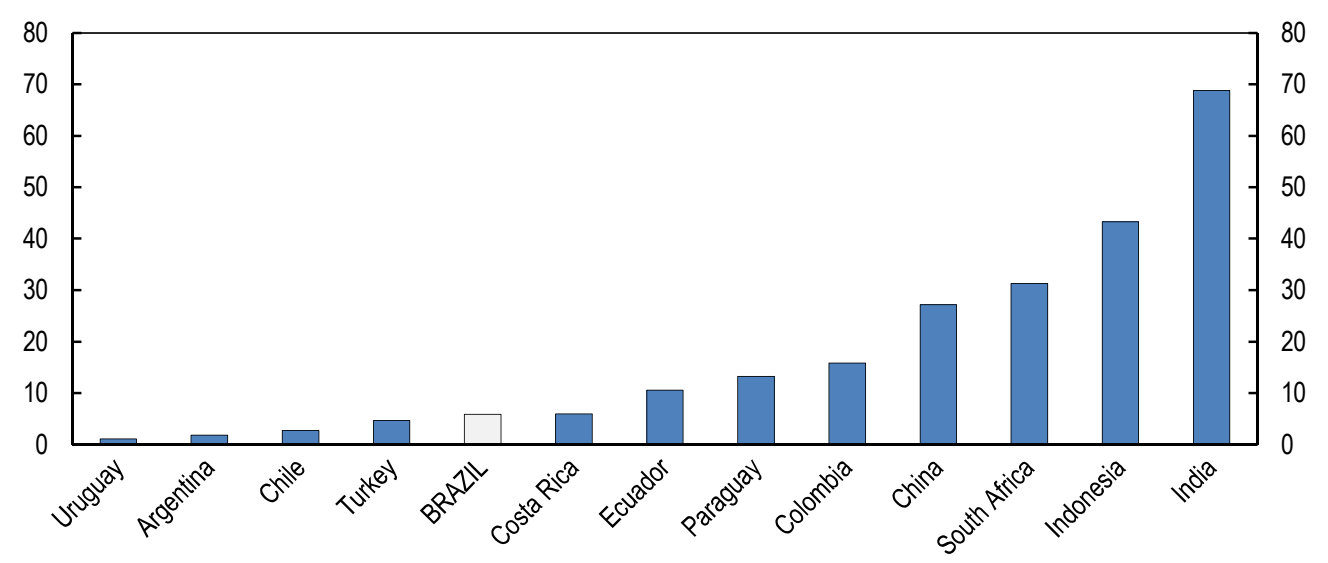

Note: The last available year is 2009-11 depending on the country, 2012 for Brazil.

Source: World Bank (2013), IPEA.

\section{The new middle class}

As a large number of households were able to leave poverty behind, the middle class has expanded so strongly that many observers have referred to it as the emergence of a "new" middle class. These households are now enjoying consumption possibilities that go much beyond the satisfaction of basic needs, and they have given a substantial boost to aggregate consumption growth. Around $53 \%$ of the population now possess a formal job, enjoy access to credit and have acquired a car or motorbike (Neri, 2011). Following the standard class definitions used in the literature, the number of people belonging to the C-class - representing the middle class - has increased from 66 million to 115 million since 2003, while the lower D- and E-classes have declined (Figure 5). In the lowest income class, the upward dynamics have been particularly rapid (Neri, 2011). At the same time, movements from the middle to the upper class have been considerably slower than from the lower to the middle class (SAE, 2012).

Figure 5. Distribution of population by income classes in Brazil (in millions)

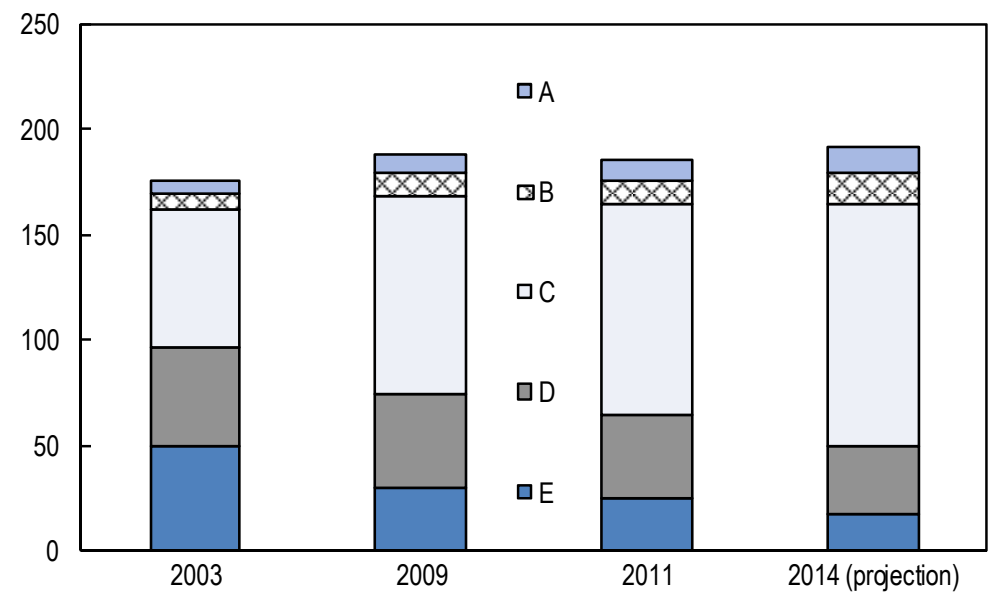

\begin{tabular}{|c|c|}
\hline \multicolumn{2}{|c|}{ Class definitions: } \\
\hline & Monthly household \\
\hline Class & income (2011 BRL) \\
\hline A: & $>9745$ \\
\hline B: & $7475-9745$ \\
\hline C: & $1734-7475$ \\
\hline D: & $1085-1734$ \\
\hline$E:$ & $<1085$ \\
\hline
\end{tabular}

Source: IBGE, IPEA, Neri (2011). 
The distributional trends that Brazil has experienced are in line with developments in some other countries in Latin America, although Brazil's performance is quite remarkable even in a regional comparison. Using purchasing-power-adjusted prices in a common currency, the regional comparison in Panel A of Figure 5 shows the weight of Brazil's middle class $-64 \%$ of the population - in the upper range of countries, although below Argentina, Chile, Costa Rica and Uruguay. Given that the last available data are 2009 for this comparison, it is likely that Brazil's position has improved relatively to other peers, given the particularly fast growth of its middle class (Figure 6, Panel B).

A closer look at the characteristics of people who have joined the middle class suggests that even members of socioeconomic groups that have traditionally been disadvantaged had fair chances to move into the middle class during the last decade, such as inhabitants of rural areas, ethnic minorities, informal workers or people with low educational attainments (Figure 7).

Figure 6. A comparison of growth and size of the middle class in Latin America

A. Class composition in select Latin American countries in 2009, in 2005 USD at purchasing power parity

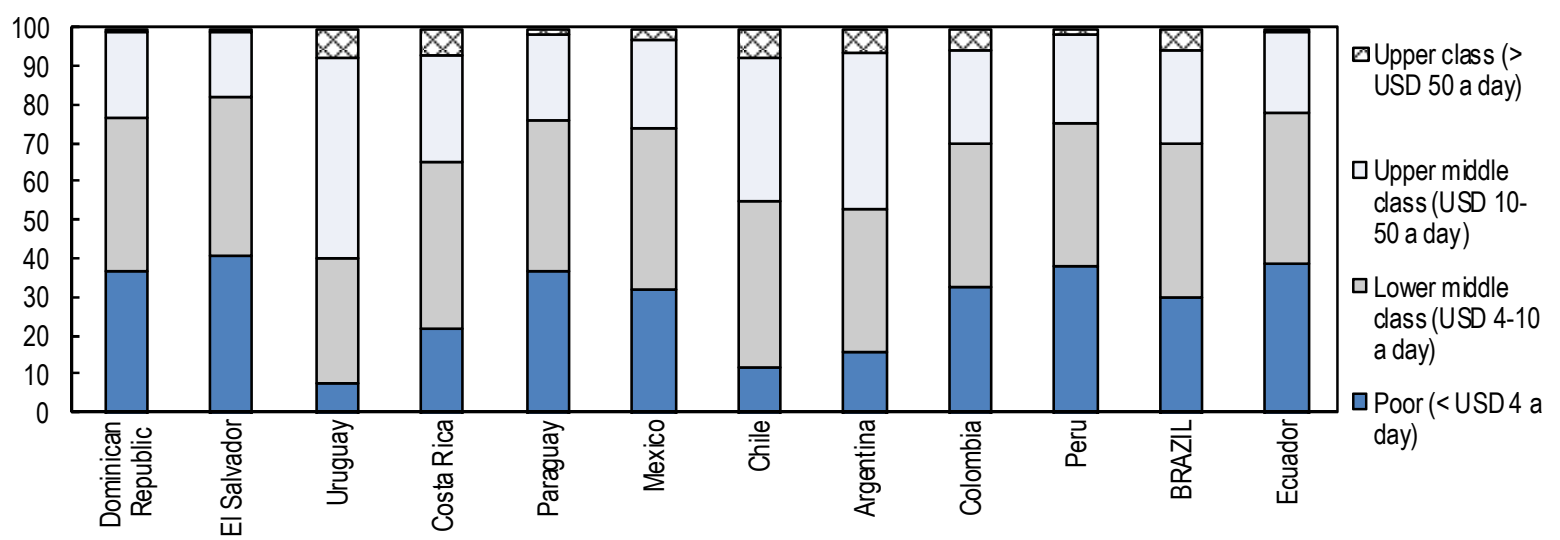

B. Growth of the middle class in select Latin American countries, 2000-2009, in 2005 USD at purchasing power parity

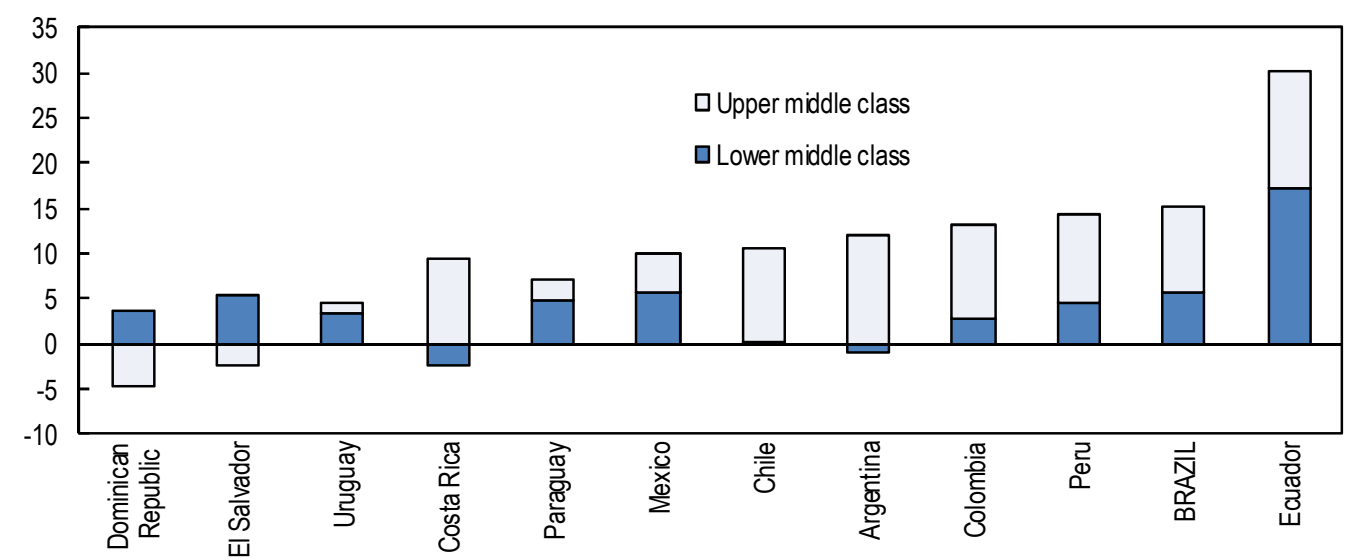

Note: Instead of 2009, the respective value for Mexico refers to 2010. For Brazil, 2000 was interpolated from the two adjacent years.

Source: Ferreira et al., (2012). 
Figure 7. Characteristics of people who joined the middle class

Per cent of people belonging to a socioeconomic group that have joined the middle class between 2002 and 2012

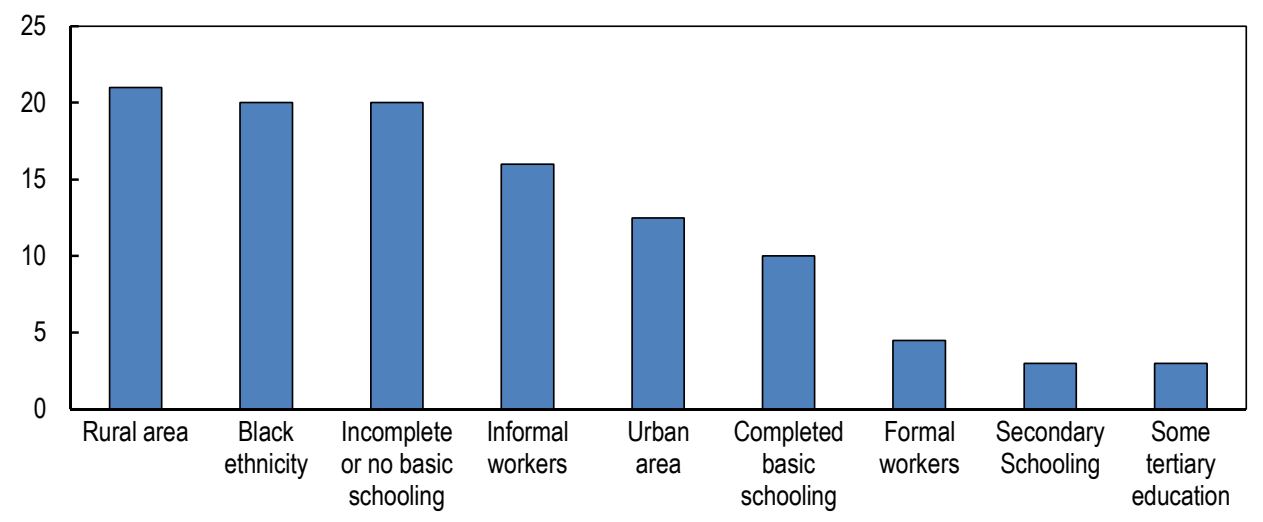

Source: SAE (2012).

The strong role of improvements in education that underpin the increase of the middle class households (see next section) suggest the sustainability of their social ascent, but there are also risks. Many middle class households finance a significant share of their consumption through credit, which has increased leverage and debt servicing costs. Rising household indebtedness levels currently amounts to $44 \%$ of annual income including mortgage debt or 30\% excluding mortgages, which is not out of line with the levels observed in Mexico and Colombia (Figure 8). However, given that households face higher interest rates in Brazil ( $34 \%$ for personal credit), the costs of servicing this debt relative to incomes is substantially higher at $21 \%$ of disposable income. This number is larger than in the other countries in the region (IMF, 2012). A number of reasons can explain the high debt service, including the high level of interest rates, short maturities, and stringent rules on paying back credit-card debt. House price indices for major metropolitan regions indicate annual increases of around $12 \%$.

Figure 8. Household indebtedness in select economies, 2011

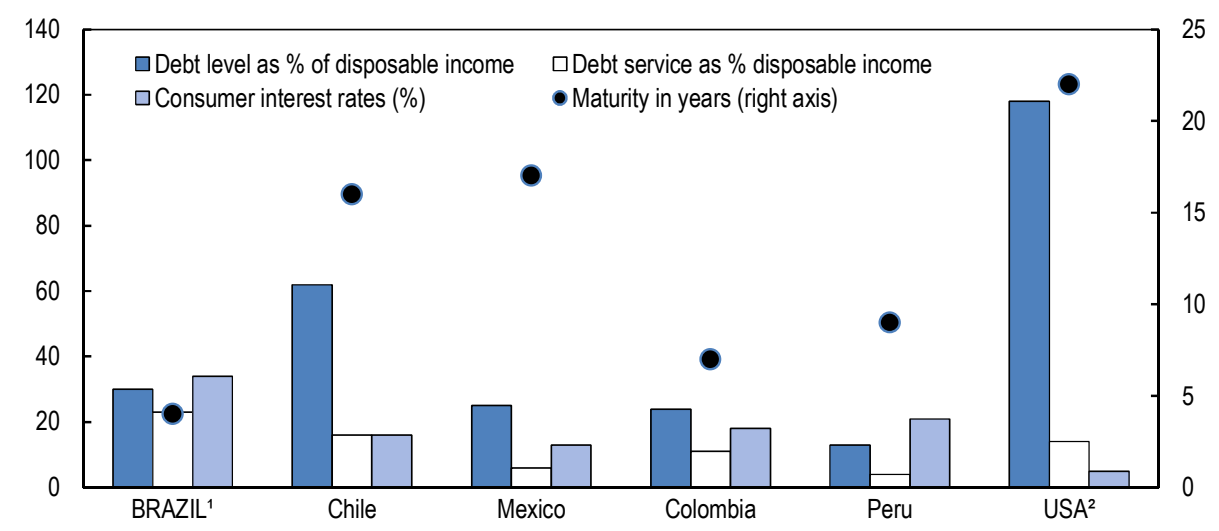

1. Data for Brazil are for 2013. Interest rates are for household credit from non-earmarked funds.

2. Data for the US are for 2010.

Source: IMF (2012), Central bank of Brazil.

\section{Regional disparities have diminished but remain high}

Regional income disparities among Brazil's states are very high (Figure 9). Average labour incomes are 4.4 times higher in Brazil's capital region Distrito Federal than in the state of Piauí, while GDP per capita is more than 8 times higher. But there has been a convergence in regional incomes in recent years, 
driven mainly by rising income levels in resource-intensive regions (Tocantins, Mato Grosso, Rondônia, Espírito Santo and Maranhão), while a number of other states appear to have been excluded from this convergence process (Amapá, Pernambuco, Pará and Ceará). Inequality within states tends to be higher in regions with lower average incomes per capita, with particular progress made in Piauí and Maranhão in the Northeast. Poorer states have also been able to lift a greater number of people out of poverty, implying a convergence in poverty rates across states (Allwine et al., 2012).

Figure 9. Average labour incomes per capita and inequality by state, 2011

Note: Based on labour incomes of employed people above age 10.

Source: PNAD 2011.

\section{The sources of social progress}

\section{Deliberate policies to improve income distribution have contributed significantly to social progress}

Brazil's social progress since the macroeconomic stabilisation has been supported by a solid growth performance, which has increased the size of the pie for the entire society, but it is also the result of deliberate policies to distribute the pie more evenly. To evaluate the contribution of policies to the observed improvements and get a sense of their effectiveness, a useful exercise is to decompose the respective contributions of the increasing pie and the improvements in distribution.

The poverty reduction of economic growth between 2001 and 2011 can be isolated, using household data, by assuming that the distribution of incomes remained constant over this period while all incomes grew proportionally to the average income growth over the period. By contrast, keeping the average income level constant while applying only the change in income distribution to the households data allows an estimate of how much redistribution alone contributed to poverty reduction. Such a decomposition reveals that between $52 \%$ and $56 \%$ of the observed decline in poverty can be traced back to growth, depending on the poverty definition applied, with the other half owing to successful policies that improved the income distribution. If the distribution of income had remained unchanged, the same observed decline in poverty would have required average incomes to rise by $89 \%$, instead of the $32 \%$ observed between 2001 and 2011 (IPEA, 2012). 
The same simulations have been applied to analyse the determinants of the rise of the growing middle class (SAE, 2012). Between 2002 and 2012 the middle class increased by $14 \%$ of the population. This increase is the net result of $21 \%$ of the population joining the middle class, and $7 \%$ leaving it - the vast majority of which upward. Applying the average income growth rate over the decade to all households without altering the distribution would have led to a net increase in the size of the middle class of only $5 \%$, instead of the $14 \%$ actually observed. In other words, approximately two thirds of the growing middle class can be attributed to improvements in the income distribution, which was strongly affected by policies, while only one third was due to growth.

\section{Education and labour market policies have improved the distribution of labour incomes}

Policies have improved the distribution of incomes through a number of channels, the most effective of which have been the effects of education and labour market policies on one hand, and social transfers on the other. Improvements in education and changes on the labour market have allowed individual to earn higher labour incomes, while the beneficial effects of rising transfer incomes are also clearly visible in household surveys.

Evidence from micro data suggests that labour income contributed the lion's share of $58 \%$ to the fall in inequality in disposable incomes between 2001 and 2011 (Figure 10). Besides labour income, social transfers have reached an increasing number of households and this has been the second largest driver of improvements in the income distribution, accounting for $23 \%$ when contributory and non-contributory pensions are counted together. Finally, conditional cash transfers are responsible for $13 \%$ of the declining inequality, although Brazil spends less than 1\% of GDP on these. This is a first indication of how effective conditional cash transfers are in the quest for more income equality, an observation on which there seems to be broad consensus in the literature (e.g. Barros et al., 2009, 2010).

Figure 10. Contributions of different factors to declining inequality

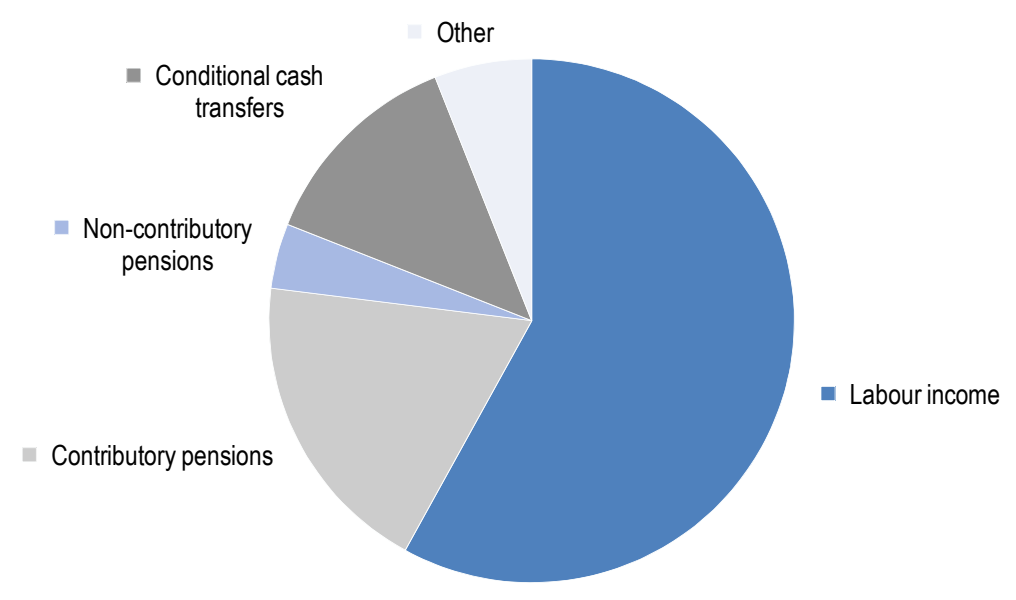

Note: Excludes households with unknown income and rural areas in the North region. Based on disposable incomes.

Source: IPEA (2012).

To further understand the sources of falling inequality, the next step is to analyse in turn why labour and transfer incomes have become more equally distributed. Household data for 2009 suggest that almost half of the differences in labour incomes can be explained by education as measured by years of schooling, even after controlling for other differences (Ferreira de Souza, 2012). This indicates that improvements in 
access to education have played a significant role for the declining inequality of labour incomes. Indeed, youth are staying in school longer than in the past, and the starkest changes have occurred among people from the lower income strata (Figure 11, Panel A). Among the two lowest income quintiles, enrolment rates of 15-17 year olds have more than doubled to $42 \%$, while for ages $6-14$, more than $98 \%$ of children are in school (PNAD, 2011). Higher school attendance has also translated into higher educational attainments. The shares of youth at age 19 with completed lower and upper secondary education have roughly doubled within a decade (Figure 11, Panel B). This has also allowed an increase in tertiary enrolments by $73 \%$ between 2003 and 2011. These improvements have also left their mark on the skills of Brazilian youths, as evidenced by the results of the OECD's PISA study which suggests that between 2000 and 2009 students gained the equivalent of a full academic year of math (OECD, 2012a). Brazil went from being the lowest performing country in 2000 to being one of the 3 fastest improving countries over the past decade, although in comparison to other countries levels continue to be low. This is despite the fact that more students from less privileged backgrounds have been included in the education system and the aptitude tests.

Figure 11. Progress in education

A. Share of people at age 19

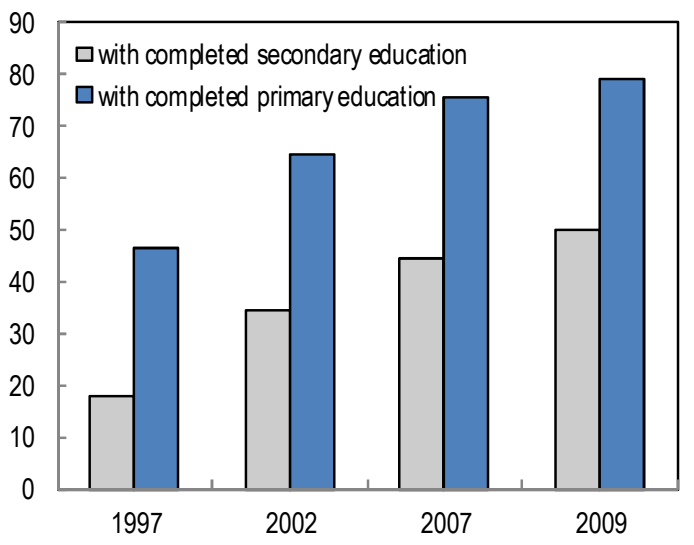

B. Enrollment rates of $15-17$ year olds by family income quintile

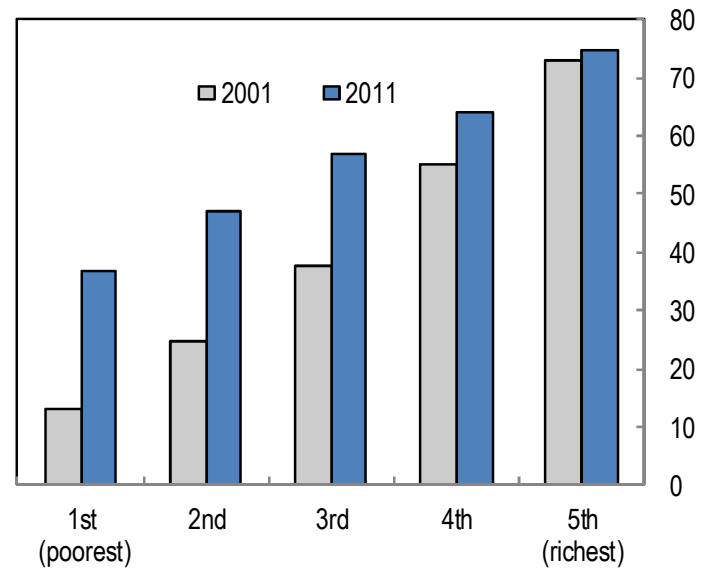

C. Educational attainments in international comparison, age group 25-34, 2011

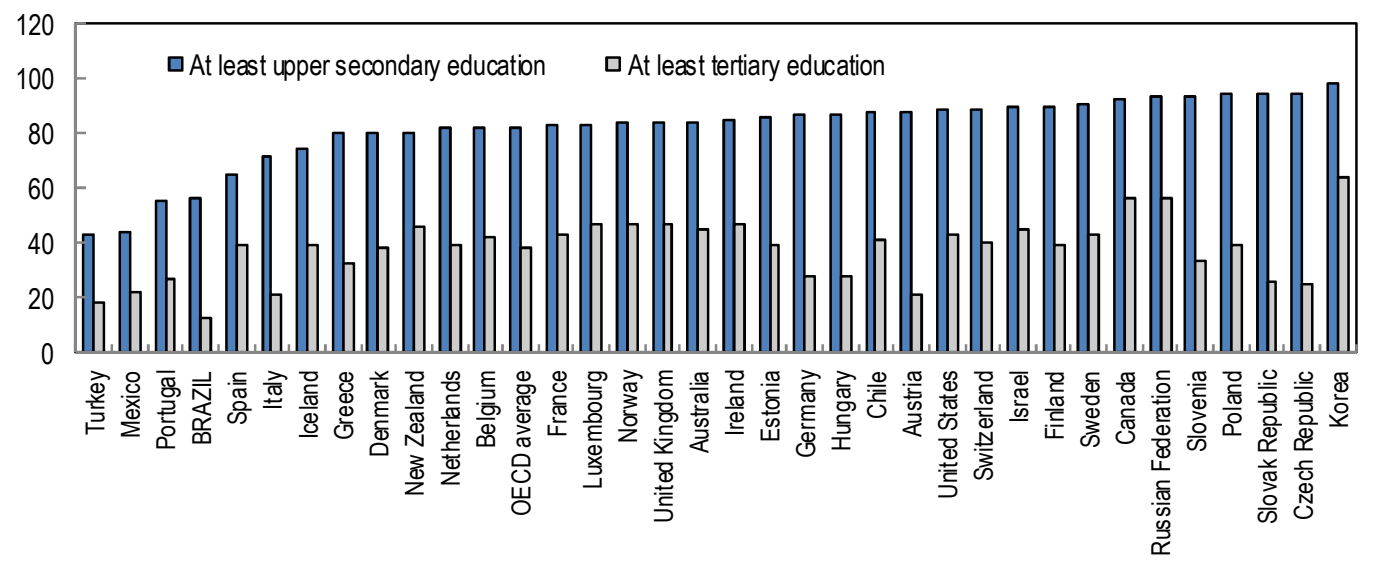

Source: IBGE (2012) and OECD (2013c). 
Exiting poverty has been highly correlated with educational achievement. Slightly over $20 \%$ of the poor household whose household head had less than primary education exited poverty between 2003 and 2011, compared to $50 \%$ of households whose head had completed primary education (Fruttero et al., 2012). As more people have attained better education, they gained access to better paying jobs. Given Brazil's sizeable skill premiums in international comparison, this has had a large impact on many households. A completed tertiary education, for example, would increase expected earnings by $45 \%$ in 2003. But as more people attained higher levels of education, skills have become less scarce and skill premiums have declined accordingly (Figure 12). The wage premium for a completed tertiary education, for example, fell to $31 \%$ in 2012 . Concretely, this meant that even people that were not able to improve their educational attainments personally saw their earning opportunities rise with the emergence of more skilled labour. In other words, improving access to education has had positive externalities on low-educated individuals.

Figure 12. Educational attainment and skill premiums

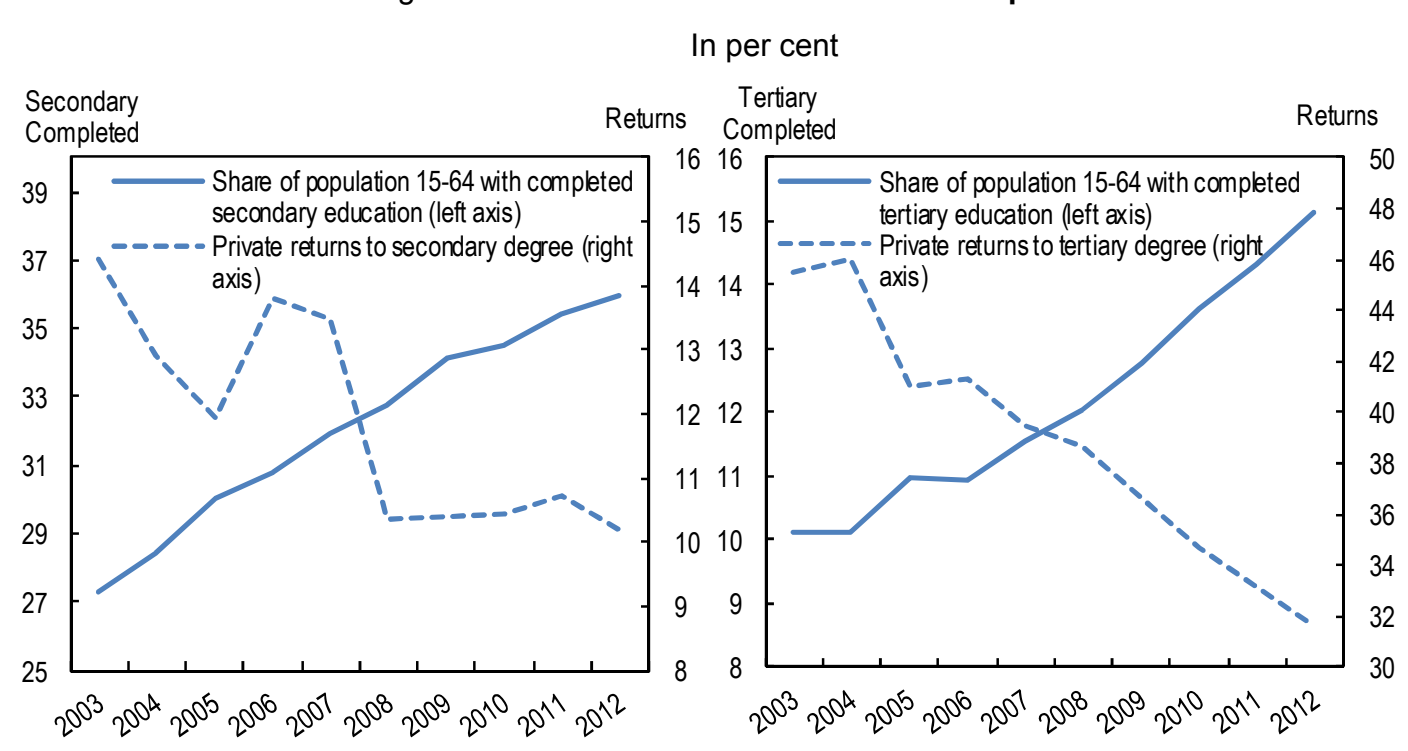

Source: OECD (2013b).

In addition to the role of skills, other developments on labour markets have also underpinned the rising labour incomes at the bottom end of the income distribution. A strong rise in minimum wages has benefited the incomes of low-income employees. Over the last decade, the real value of the minimum wage has almost doubled, while the average real wage has risen by around $25 \%$ (Figure 13). This has compressed wages in the formal sector, and improved the relative earnings of those receiving the minimum wage. The level of Brazil's minimum wage relative to the earning of other employees has become an outlier in international comparison. At $69 \%$ of the median wage, Brazil's minimum wage was the second highest in that comparison among OECD and BRIICS countries (behind Turkey) in 2011, with the OECD average being at $49 \%$, although the absolute level of the minimum wage remains low compared to OECD countries (OECD, 2013a). While unemployment has decreased steadily over the years, labour market informality in the main metropolitan areas has fallen from 55\% in 2001 to $33 \%$ in 2013, supported by special tax and registration regimes that made it easier for small enterprises to declare formal employees with a minimum of bureaucracy and a low tax burden. At the same time, the rising minimum wages have been associated with a structural shift of the economy towards non-tradable sectors, which suggests that international competitiveness may have been affected by the strong minimum wage increases, even if unemployment has not (see Chapter 1). 
Figure 13. Real minimum wages and average wages

12-months moving averages, Feb $2003=100$

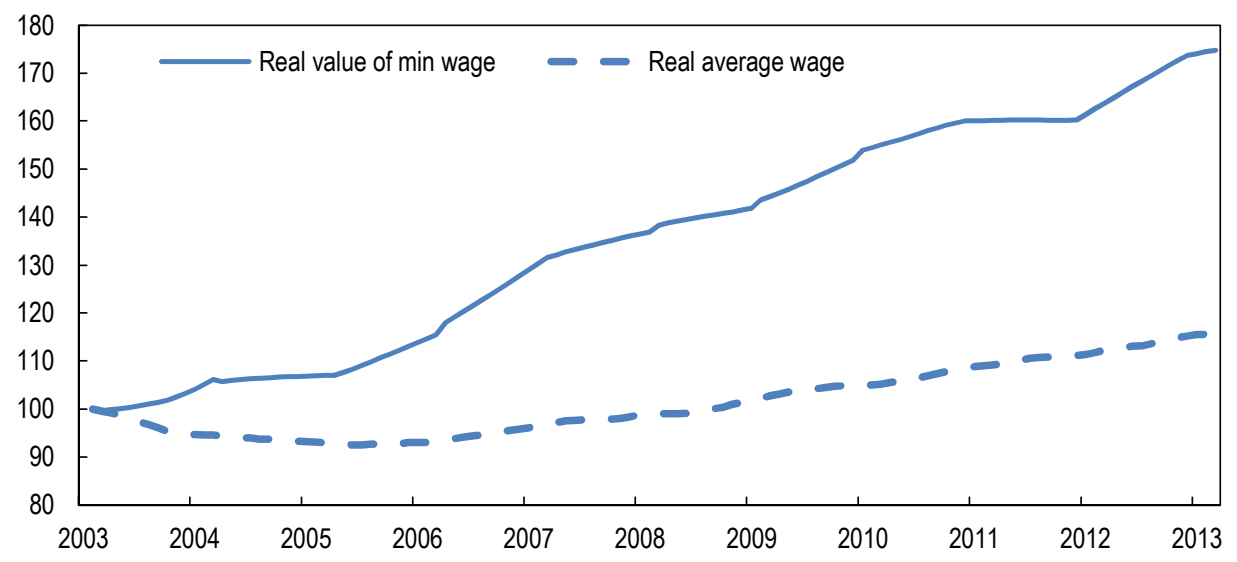

Source: IBGE.

\section{Social transfer programmes have played an important role}

Transfers have been the second pillar of Brazil's social progress. Transfers comprise a wide range of heterogeneous policies, designed around a number of policy objectives. From the perspective of poverty and inequality, the most important ones are pensions and the conditional cash transfer programme Bolsa Familia which is now part of the larger policy package Brasil Sem Miseria (Brazil without Misery).

Based on a fairly complete nationwide single registry of poor households and their living conditions, Bolsa Familia was designed to provide direct transfers (as opposed to in-kind support) to households whose monthly per capita income is below BRL 70 (Soares, 2012). While initially some of the benefits were available only to households with children, households without children have by now become eligible for all the benefits necessary to lift them above the poverty line. Beneficiaries must meet a series of conditions such as keeping their children in school and regular health check-ups, which adds a sustainability element to the programme and lays the foundations for families to move out of poverty over time. Since poverty is highly concentrated in the Northeast region, more than $50 \%$ of Bolsa Familia transfers are paid out in this region, which also reduces regional inequalities (OECD, 2011b).

Over the years, the programme has expanded in several dimensions (Table 1) and it has proven a powerful and well-targeted tool to reduce poverty, with hardly any leakage. This is the reason why its impact on the incidence of poverty has been so remarkable, despite costing less than $1 \%$ of GDP. In particular, Bolsa Familia has proven to be a very effective tool for fighting child poverty (Afonso et al., 2011).

Beyond this traditional anti-poverty programme, pensions - which amount to around 7\% of GDP have also contributed to reducing inequality and poverty. The primary objective of the pension system is to act as a saving vehicle and provide incomes to the retired, providing for a link between individual contributions during working life and future pensions. At the same time, pension payments deviate from individual contributions in a number of instances, introducing a sizeable redistributive element into the system. This is particularly the case for people who have made low contributions to the system during their working life and for whom the system tends to be more generous than for those with higher contributions. 
Table 1. Bolsa Familia characteristics over time

\begin{tabular}{cccc}
\hline Year & $\begin{array}{c}\text { Number of } \\
\text { beneficiaries }\end{array}$ & $\begin{array}{c}\text { Average value of } \\
\text { benefit }\end{array}$ & $\begin{array}{c}\text { Expenditure as \% } \\
\text { of GDP }\end{array}$ \\
\hline 2004 & 6571839 & 67 & 0.3 \\
2005 & 8700445 & 63 & 0.3 \\
2006 & 10965810 & 63 & 0.3 \\
2007 & 11043076 & 75 & 0.4 \\
2008 & 10557996 & 86 & 0.4 \\
2009 & 12370915 & 95 & 0.4 \\
2010 & 12778220 & 97 & 0.4 \\
2011 & 13352306 & 120 & 0.4 \\
2012 & 13724590 & 150 & 0.5 \\
\hline
\end{tabular}

Source: IPEA data and Ministério do Desenvolvimento Social e Combate à Fome (MDS).

To prevent pensioners' incomes from falling behind the rest of the population, the minimum pension benefit payable by the social security system is required by law to be as high as the federal minimum wage. This is exceptionally generous by international standards, as most OECD countries have a minimum pension level lower than the minimum wage. This rule also means that any upward revision to the minimum wage has immediate fiscal consequences. In fact, changes in the minimum wage affect more people's incomes through their effect on social transfers than through their effect on wages. Over the last decade, the real value of the minimum wage has almost doubled, and this has affected the large share of pension recipients who receive the minimum pension benefit. As a result of this constellation, the pension system pays out average benefits that are fairly generous in international comparison, with net replacement rates for average earners at 97\%, compared to an OECD average of 69\% (Figure 14).

Figure 14. Net pension replacement rates: average earners

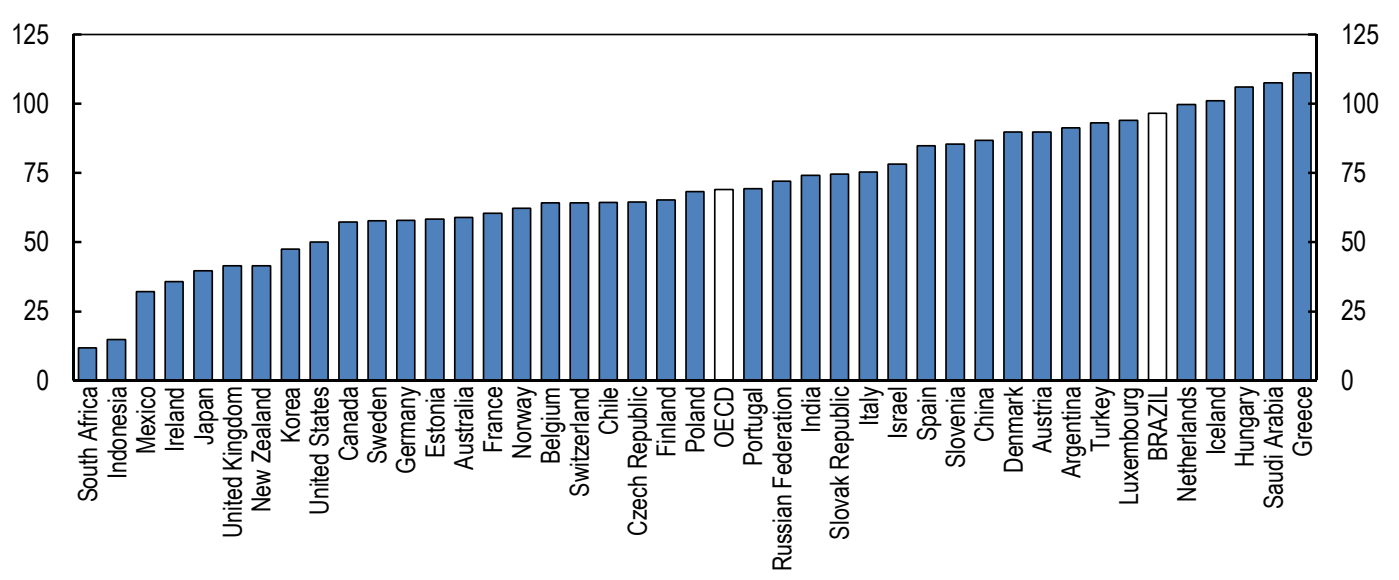

Source: OECD (2011e).

Besides the regular contributory pension system, there are several smaller pension programmes allowing additional benefits targeted at specific groups. One is the non-contributory pension system, consisting of the social assistance pensions and the Rural Social Security programme. Both programmes extend coverage to persons above 65 years of age who are unable to fulfill the usual contribution criteria, and provide pension benefits at the level of the minimum wage. People with disabilities are also covered 
under these schemes, whose existence explains the almost universal coverage of the elderly under Brazil's social security system. This is a part of the pension system that covers a fairly small part of the pension beneficiaries (around 3\% in 2009), but has a high poverty impact. At the same time, the system fails to reward workers that have contributed during their working life while earning minimum wages, because they receive no additional pension benefit over an individual who never paid into the social security system.

Another programme grants survivor pensions at the full value of the retirement pension paid or payable to the deceased. These benefits can be accumulated with the beneficiary's own retirement benefit, and almost half the beneficiaries have other sources of income (Mesquita and Neto, 2010). As a result, per-capita income typically rises with the passing of a family member. In 2011 Brazil spent $2.8 \%$ of GDP for survivor benefits, which is almost a quarter of total social security expenditure. For comparison, most countries in Europe spend around 1.6\% of GDP on this kind of pensions. The system presents strong incentives for abuse. For example, a young person marrying a pensioner will be eligible to the spouse's pension for the rest of life, even if the marriage lasted only a few days and without any means testing.

\section{Policy options for sustaining and enhancing social progress}

Brazil's social achievements have been remarkable, and many good policy choices have supported this progress. But as people manage to move out of poverty, there is always a risk of falling back, and future policies will need to ensure that the positive developments of the last decade become more sustainable. Beyond that, the sizeable number of Brazilians who are still struggling to meet all their basic needs call for further progress at an even faster pace than in the past. Indeed many indicators suggest that in terms of the level of social inclusion, much more work remains to be done in Brazil.

Policy should continue to focus on the broad set of instruments that has been successful in the past: the improvement of public services such as education, but also health and transport services and social transfers. In addition to these, as addressed below, more attention could be paid to the potential role of the tax system for reducing income inequality, and to developments in consumer credit markets. Within these broad areas, there may be scope for rethinking the allocation of resources and the reliance on a particular policy mix. Given how much Brazil has changed over the years, policymakers should not take for granted that what has worked well in the past will deliver best results in the future. This is particularly true for the allocation of resources in the area of social transfers.

\section{Provision of public services}

The public sector provides a number of essential services, and many of these have played key roles for reducing poverty and inequality, as argued in the preceding section. Education is probably the most prominent example for such public services, but other areas may play important roles as well, including health and transport policies. Despite much progress, a significant share of Brazil's population lacks access to essential services. In 2011 nearly $22 \%$ of the population lived in a household where no resident had completed at least 8 years of schooling, although ten years earlier this share was almost twice as high (Figure 15). Also, a quarter of Brazilians live in dwellings with no access to a sewage network or septic tank, while $7 \%$ of dwellings have no access to piped water or wells. The perceived quality of public services, in particular in light of Brazil's high tax burden (see Chapter 1), was one of the issues that prompted many Brazilians to take to the streets in June 2013, which highlights the importance of improvements in this area. 
Figure 15. Share of population deprived of access to basic goods and services

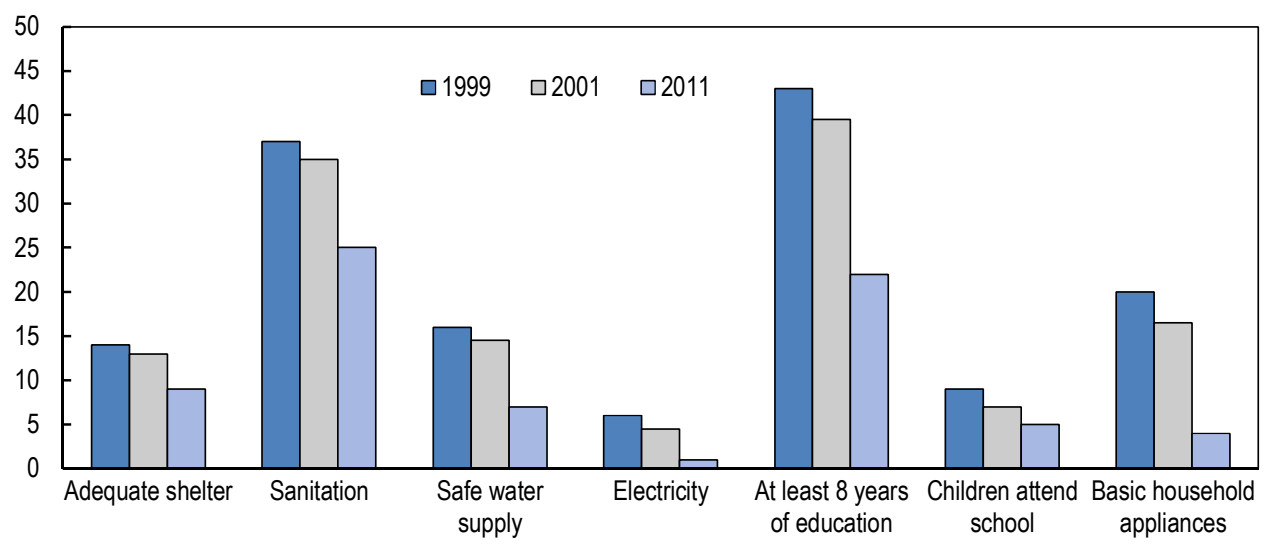

Source: Bianchi et al., (2012).

In Brazil's federal system, many public services are delivered by state or municipal authorities, and capacities to deliver public services can vary substantially across jurisdictions. Beyond that, for municipal services, the size of a municipality may not necessarily coincide with the most efficient scale at which to provide a given service, in which case there is scope to improve service efficiency by having several municipalities join hands for the delivery of services, but this involves significant coordination challenges. One example where successful ways have been found to address such challenges is the central government's "Territories of Citizenship" initiative, launched in 2008 to support development in poor rural areas. Many projects included in the initiative have successfully enhanced capacity at municipal level, increased citizen participation and accountability and enhanced the coordination of sectoral policies at the federal level.

\section{Educational policies}

Education has played a key role for social progress in the past, and will continue to be paramount in the future. Following the advances in terms of access to education described in the preceding section, one of the principal challenges going forward will be to improve the quality of education. Competencies of school-aged children have increased over the years as enrolment rates improved, but compared to international benchmarks, Brazilian students still learn significantly less. The OECD PISA programme assesses 15-year-olds' competencies across 70 countries, and allows direct comparisons (OECD, 2012a). Despite a $92 \%$ enrolment rate in education up to age 14, Brazilian youths still underperform their peers from other countries significantly in terms of competencies (Figure 16). This suggests that the bottleneck is no longer access but quality. The quality of public secondary schools tends to be lower than that of private schools, resulting in easier access to high-quality public tertiary education for graduates from private secondary schools. However, a law enacted in 2012 reserves 50\% of places in public universities for students from public secondary schools or disadvantaged backgrounds. There are also strong geographic disparities, with students in the North-East region - where adult illiteracy still is close to $20 \%$ - scoring particularly low in the tests.

To some extent, lower quality of education is the natural consequence of an education system that has expanded rapidly over the last years, and as time goes by, the system should be able to recruit better-trained teachers in sufficient quantities. What is essential for this improvement to be realised, however, is to improve teacher training and create the right performance incentives now. While the provision of education is the responsibility of the states, the federal Ministry of Education (MEC) has played an important role in this context. 
Figure 16. PISA scores on reading and mathematics

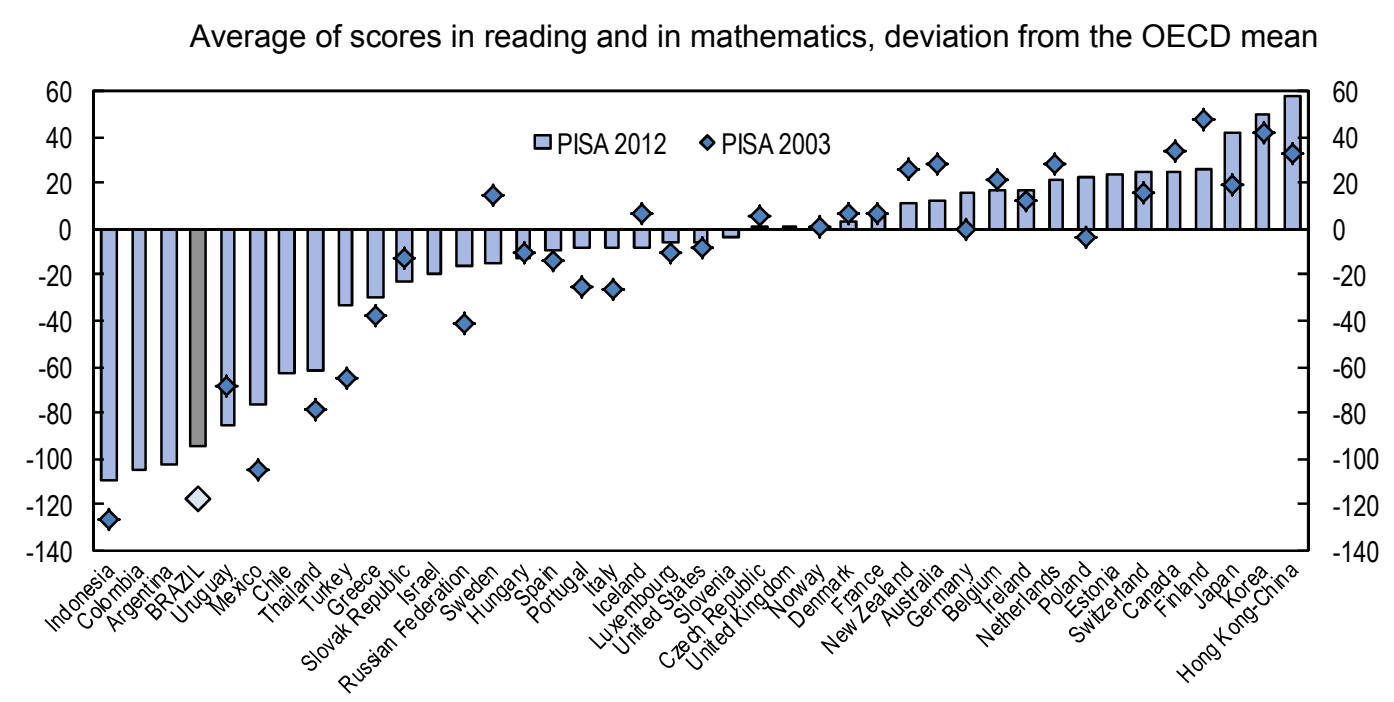

Source: OECD (2011a, 2013e).

To some extent, lower quality of education is the natural consequence of an education system that has expanded rapidly over the last years, and as time goes by, the system should be able to recruit better-trained teachers in sufficient quantities. What is essential for this improvement to be realised, however, is to improve teacher training and create the right performance incentives now. While the provision of education is the responsibility of the states, the federal Ministry of Education (MEC) has played an important role in this context.

With regard to teacher training capacity, the MEC has created a new national exam for entrants into the teaching profession, and has collaborated with federal universities to fund 100000 new training places for teachers. In addition, it has required states and municipalities to establish a formal recruitment process and career plan for teachers, and set a nationwide floor for teacher pay in 2009. In-service training to improve the capabilities of existing teachers has become more prominent, and some states have founded specific schools for training current teachers.

Concerning performance incentives, the federal government has provided additional funding to equalise and top up per student school funding across regions, states and municipalities via the FUNDEB programme, and much of this funding is coupled to performance improvements. Brazil has established a set of nationwide student competency tests after the 4th, 8th and 11th grades that allow almost every school in the country to be benchmarked, and this has proven tremendously helpful for introducing incentive mechanisms. A reform of the school assessment system, with targets for learning outcomes down to the school level in all regions, rewards schools not only for improving results but also for student retention, and this reform is beginning to show results. Some states have also devised promising incentive mechanisms of their own. For example, the state of São Paulo offers regular performance tests to teachers with pay rises conditional on test outcomes. Two more states have also adopted similar procedures, which continue to be an exception in a system where pay scales are largely dominated by seniority. The early empirical evidence suggests visible improvements in student aptitudes, with schools with more ambitious targets achieving more progress (Bruns and Ferraz, forthcoming). Extending such performance-based pay nationwide would be a useful measure.

Another impediment to better teaching quality is the lack of physical infrastructure, with many school buildings operating in several shifts a day. Most secondary students receive only 4 hours of instruction a day, while the average in OECD countries is 7 hours (World Bank, 2012). Only 5.8\% of students up to 
age 14 receive full-day schooling (OECD, 2011a). In addition, teachers in Brazil spend less time on actual teaching and learning activities than in other countries (OECD, 2013d, p. 33). International evidence suggests that increasing instruction time has a positive performance effect, provided that the curriculum remains focused on core subjects (Glewwe et al., 2011). Additional investment in appropriate education infrastructure, including class rooms, libraries, science labs and computer facilities should therefore be undertaken. These facilities have become standard in most OECD countries.

An aspect of the education system that is particularly relevant from a distributional angle is the high number of drop-outs and the disengagement of some groups from the education system. Almost $10 \%$ of students leave secondary school in a given year. In many instances, this affects youths from disadvantaged backgrounds, who have been exposed to social issues such as family instability, gang or drug involvement, teen pregnancy or developmental deficits (World Bank, 2012). If these youths simply drop out from schools, future earning opportunities for such disadvantaged youths are reduced even further. Drop-outs can be reduced through action in a number of dimensions, including early childhood education, targeted assistance during primary and secondary school and sufficient flexibility of the curriculum including a stronger vocational focus.

Early childhood education (ECE) has important short and long-term effects on cognitive development, social behaviour and students' ability to succeed in the education system and on labour markets further on. In the United States, both early experience in the 1970s that allow a long-term evaluation and more recent evidence from the state of Oklahoma suggest strong benefits associated with ECE (Heckman and Masterov, 2007). In fact, marginal returns on spending appear to be higher than anywhere else in the US education system. When looking at how children from ECE programmes perform later on in life, evidence suggests complementarities between ECE and later education investments (Felicio et al., 2012). Children from disadvantaged family backgrounds that are at risk of receiving less attention than others during their early childhood years can benefit particularly strongly from ECE enrolment. For this reason, ECE also improves the equality of opportunities and strengthens social mobility.

While 55\% of 4-year olds are enrolled in ECE programmes in Brazil, the OECD average enrollment at that age is $79 \%$, with a number of countries reaching almost full coverage (France, Netherlands, Spain, Mexico, Belgium, see Figure 17). A lack of funding is one of the reasons for low enrolment rates, although federal funding is available to support the current expenditures of operating childcare centres and building pre-schools has been one element of the infrastructure programme PAC2. In addition, the federal ProInfancia programme provides financial support for the costs of building and equipping childcare centres. It has so far funded over 2000 centres and provided resources to equip several hundred more (Evans and Kosec, 2012). Federal support for ECE should be continued and expanded to reach the ambitious objective of the new National Education Plan (PNE) of achieving universal enrolment of 3 and 4-year-olds by 2016. In comparison to the 40 countries covered in the OECD's Education at a Glance study, Brazil is placed in the bottom quarter of countries with respect to expenditure on early childhood education relative to GDP (OECD, 2012a).

While widening access to ECE programmes, particularly in disadvantaged areas, will be the most immediate priority, its quality could also be improved, including through more intense training and supervision of educators (Early et al., 2007). In Denmark, France and Sweden a sizeable proportion of childhood education workers are required to have specialised training (Moss, 2000). The Brazilian Federal Ministry of Education operates a distance-learning programme for ECE educators called ProInfantil, on which efforts to improve training could build. Regular in-class observation by experts coupled with real-time feedback has proven a useful tool in the PERA programme of the US state of Illinois. The Ministry of Education could also support municipalities in applying benchmarking mechanisms such as the "Early Childhood Environment Rating Scale" developed in the United States. 


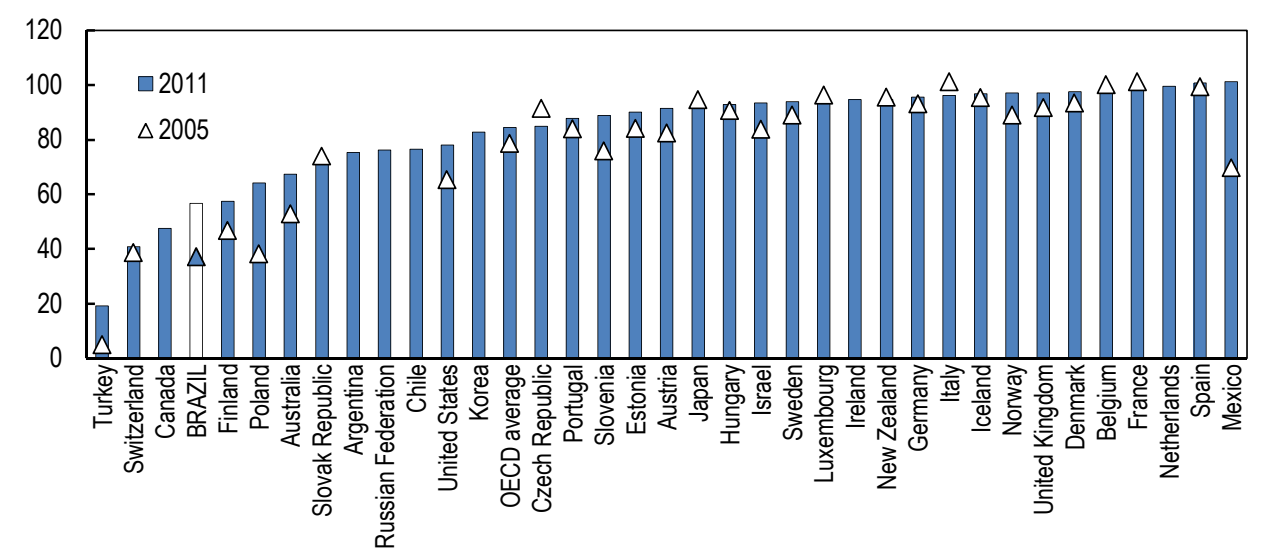

Source: OECD (2012a). For Argentina: UNESCO Institute for Statistics (World Education Indicators Programme).

While ECE can reduce drop-out rates by addressing some of the underlying problems before they occur, targeted support to those at risk of leaving the education system should be available during primary and secondary education. Useful remedial interventions that are consistent with global best practices include early detection and tailored support with tutoring classes (Glewwe et al., 2011; Guimaraes and Sampaio, 2013). Increasing flexibility in the way qualifications are acquired could attract more students, such as organising school years by semesters or adopting credit systems (Barros et al., 2012). More subject choice should be introduced in secondary education as the curriculum is heavily standardised and academically focused (Schwartzman, 2010). A curriculum reform could integrate more vocational components for those students who are less academically inclined (Bassi et al., 2012). Some of the attempts to address the issue appear promising and should be pursued further, such as the comprehensive youth programme ProJovem Integrado launched in 2008, which aims to reengage disadvantaged youth with the education system.

International experience suggests that grade repetition has high costs and doubtful benefits (OECD 2011a). Brazil has one of the highest proportion of students repeating a grade and significant numbers of students in a given grade are over-aged, which constitutes a waste of students' time and system resources. Already in the first grade, repetition rates are $24.5 \%$ (United Nations, 2012). More than $40 \%$ of 15 year-old students reported having repeated a grade at least once, compared to an OECD average of $13 \%$. In countries where more students repeat grades, overall performance tends to be lower and social background has a stronger impact on learning outcomes than in countries where fewer students repeat grades, although it is hard to ascertain the dominant direction of causality (OECD, 2011b).

Vocational training is another way to offer education opportunities to students who are disengaged with an academically-oriented curriculum. The number of students enrolled in alternative learning programs, such as upper secondary vocational education, has more than doubled in the last 10 years. However, it still represents a small fraction of total enrolments, below the OECD average, despite evidence that returns are high and labour market outcomes are positive (OECD, 2012). The Pronatec programme launched in 2011 aims to expand and strengthen the federal network of technical schools, invest in distance learning courses, provide free training places for young people from poor backgrounds and give financial support through loans and bursaries. Overcoming liquidity constraints through bursaries is an important pillar of this strategy, as financial reasons are a common explanation for not attending or finishing professional qualification and vocational courses (Ministry of Education, 2009; Neti, 2012). 


\section{Health policies}

Basic health services are provided to the population by the public Unified Health System (SUS) free of charge. The 1988 constitution established health as a fundamental right and the responsibility of states, which resulted in increased access to primary and emergency care, in addition to achieving universal coverage of vaccination and prenatal care (Paim et al., 2011). SUS is funded by tax revenues and social contributions. Service delivery is strongly decentralised, which has led to a fragmentation in the delivery of services and inequalities in the distribution of health system resources, as not all municipalities are capable of delivering services to people and economies of scale are often not exploited sufficiently.

Despite the success of the SUS, the Brazilian public health system suffers from chronic underfunding. Brazil's public sector invests about $4 \%$ of GDP in health, compared to almost $6.5 \%$ of GDP in OECD countries. As a result, medical infrastructure and the number of doctors and nurses are insufficient, with 1.8 doctors and 0.9 nurses per 1000 inhabitants in 2009, compared to OECD averages of 3.1 and 8.4, respectively (Figure 18). This shortage of medical staff leads to insufficient access to basic health care services.

Figure 18. Physicians per 1000 population

2011 or nearest year

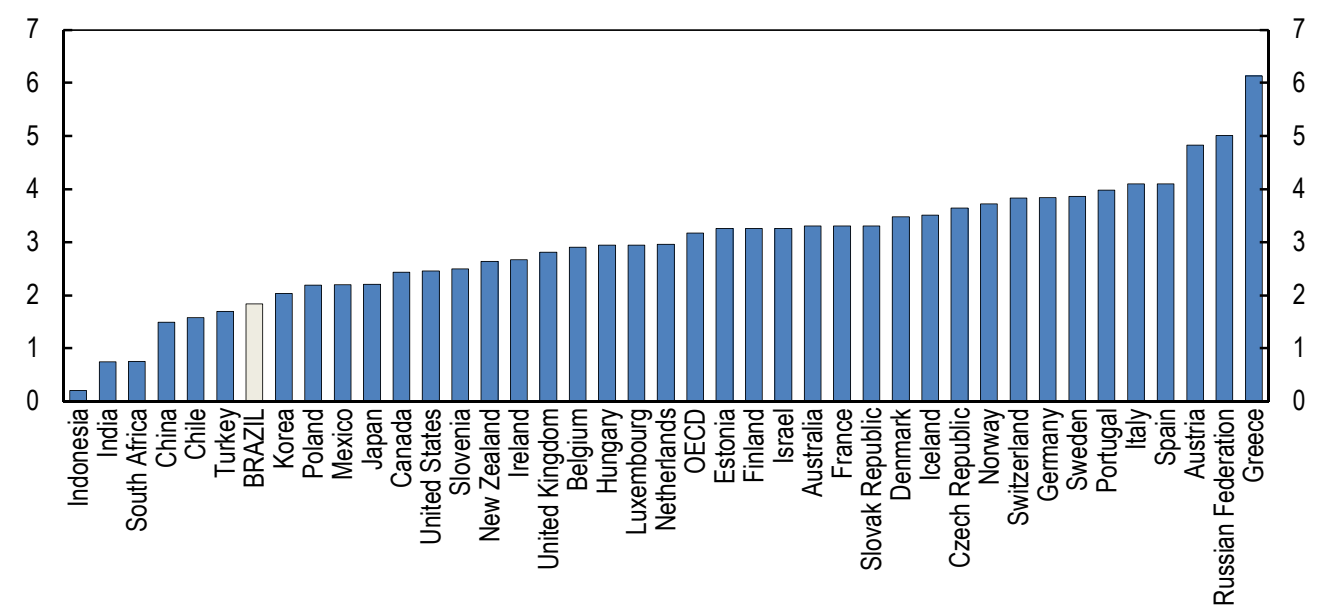

Source: OECD Health data 2013.

Catching up with the OECD average would require a 70\% increase in the number of doctors, and a much larger increase in the number of nurses. Despite recent increases in training capacity, Brazil is currently not training enough doctors and nurses to keep up with demand. The measure to require new medical graduates to serve in the SUS for two years before their degree becomes officially valid - discussed in July 2013 - can be useful if supervision is ensured, as it would boost the number of doctors available to the public system in the short term. However the experience form OECD countries suggest that increasing overall supply of doctors does not necessarily help to rectify geographic imbalances. Recent attempts to recruit foreign doctors are unlikely to make any noticeable difference, even provided that they can be successfully attracted. Of the estimated 388000 doctors in Brazil, about only $0.6 \%$ of them are foreign trained non-Brazilians. Even a multiple of this share - which is ambitious given similar shortages in other lusophone or hispanophone countries besides $\mathrm{Cuba}$ - would have only a negligible impact on Brazil's doctor shortage. Besides the quantity of health professionals, nurses in public health services tend to have low qualification levels, which may impede the delivery of high quality services. 
Beyond the number and skill level of health professionals, regional disparities and lack of access to specialty care need to be addressed. Regional disparities in the availability of human resources are strong, with the South and Southeast regions being twice as well served as the rest of the country. The capacity of municipalities to deliver health services varies. Therefore, the quality and type of services offered vary. Beyond primary care, there is limited access to diagnostics services and specialist care within the public system, with long waiting times and high out-of-pocket costs. This has clearly negative consequences in terms of inequality as the poorer parts of the population cannot access the costly private health system and suffer from a lower quality health service.

\section{Urban transportation services}

The poor state of urban transportation in Brazil has been a factor in igniting recent street protest, and indeed, virtually all major Brazilian urban centres suffer severe transport bottlenecks. While São Paulo's metropolitan underground railway system has $71 \mathrm{~km}$ of rail tracks, Mexico City has more than $200 \mathrm{~km}$. Improving urban transport systems is one of the focuses of the Growth Acceleration Programme PAC2, which is meant to fund infrastructure investments across Brazil.

However, a lack of local administrative capacity and complicated administrative procedures seem to be holding back progress. Strengthening the capacity of local governments to execute projects, such as by withdrawing unused funds quicker and making such local administrative failure public, might be one way forward. To the extent that user charges are reduced or scheduled increases are not allowed to occur in response to recent street protests, it is important to ensure that the result will not be further reductions in the funds available for investment. The cost of investing in urban transportation could be reduced by reconsidering local content restrictions under the PAC2 programme, which are at $80 \%$ for a number of manufactured goods such as buses.

\section{The future of social transfers}

Social transfers have played a significant role in fighting poverty and reducing income inequality in the past, and will continue to be an important policy tool in the future. The principal challenge for the future will be to rely more strongly on the policy instruments that are most effective in addressing poverty and that deliver the most results on social expenditure. In particular, this means giving a higher priority to increasing expenditure on Bolsa Familia and other complementary programmes within the Brasil sem Miseria framework rather than on further pension increases. Evidence suggests that the effect of a marginal increase in Bolsa Familia benefits on inequality would be many times greater than for pension increases (IPEA, 2012).

\section{Managing expenditure increases in the pension system}

Pensions have undoubtedly played a significant role in the quest against old-age poverty, and they have been very successful in reducing it well below the population-wide average, as Figure 19 shows on the basis of data from 2009. At present, all pension recipients - and this includes almost all people aged 65 and above - receive at least the minimum wage, which is almost 10 times as much as the extreme poverty line of BRL 70. Further real increases in the level of the minimum pension will hence have hardly any poverty impact, while at the same time, poverty is significantly above average among children and youths (Barros et al., 2010). Such increases could still reduce inequality since minimum pension recipients have incomes below the national average, but the inequality reduction that could be achieved by allocating the same funds to the poorest would be much greater. 
Figure 19. Poverty impact of public transfers by age group, 2009

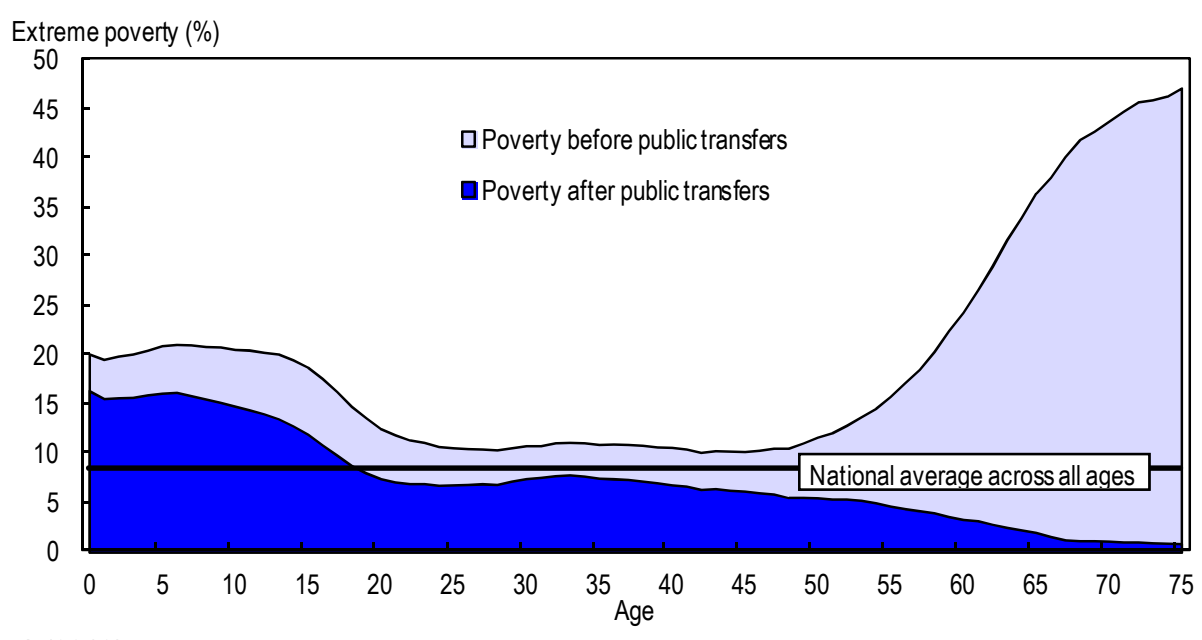

Source: Barros et al. (2010).

Severing the automatic link between the minimum pension and the minimum wage will be required to prevent the pension system from absorbing an increasing amount of social expenditures that could be used in a more effective and targeted way to combat poverty. It will also help to address long-term fiscal challenges for the pension system related to a rising old-age dependency ratio. Addressing this problem sooner rather than later is likely to make any adjustment easier. This should be done in a way that preserves the real value of pensions, while in addition passing on part of the productivity gains achieved by the current working generation. Preserving the purchasing power of pensions would be achieved by indexing minimum pension increases at least to the inflation rate for low-income households, which has been slightly above general consumer price inflation in recent years. Beyond this inflation-adjustment, the political question is how much of the productivity gains achieved by the current working generation should be passed on to pensioners, or in other words, at which point between inflation-adjustment and average wage increases the pension indexing factor should be placed. The current automatic rule passes on the full amount of productivity increases achieved by the current working generation to pensioners with minimum pension benefits. An alternative rule that would pass on only part of these productivity gains, while ensuring that the purchasing power of pensions continues to rise, would not raise poverty but it could exacerbate income inequality in the short run. However, if part of the resulting savings are directed towards Bolsa Familia to raise benefit levels and thereby minimum incomes, as recommended in this survey, inequality would almost certainly decrease. One possibility would be to pick the middle of that range, such as the choice made by Switzerland.

In addition, Brazil's pension system, which is comparatively generous in relation to working-life incomes even if absolute levels of benefits are lower than in OECD countries, could be brought more into line with current practice in OECD countries and other emerging economies by raising effective retirement ages. This could be achieved through the introduction of a general minimum retirement age and stronger incentives to retire later, as discussed in the 2011 OECD Economic Survey of Brazil. A successfully implemented reform of the pension system for civil servants is a step into the right direction.

There is also scope to reduce pension expenses by subjecting survivor pensions to means testing and defining some threshold level of income at which survivors become ineligible for a survivor pension. In addition, given the evidence of abuse in this area (Gragnolati et al., 2011), survivor pensions could be made subject to a minimum number of years of marriage or to additional contributions during working life in order to insure a surviving spouse, as practised in Sweden. 
Beyond the implications for social expenditures, continuing the current pace of minimum wage increases may also bear other risks. Although the economy is currently at full employment, the recent past has been characterised by a structural shift of the economy towards non-tradable sectors, which present less scope for productivity gains. A further deterioration of competitiveness in the tradable sector, in particular manufacturing, could at some point also have more visible effects on unemployment than is currently the case. A window of opportunity for revising the minimum wage rule will open in 2014, the last year for which the current automatic rule determining minimum wage increases based on past real GDP growth will apply. Replacing the current rule, which is set to expire in 2015, with one that links the minimum wage solely to the consumer price index for low-income households would both preserve living standards and help improve international competitiveness. Individual states that wish to set a higher minimum wage at the state level are free to do so under current law. Given that state-level minimum wages have no effects on benefit levels in the social transfer system, this would also further the objective of giving priority to the most effective transfer instruments.

\section{Expanding and improving the successful cash transfer programme}

Bolsa Familia and related social assistance programmes under the umbrella of Brasil sem Miseria have managed to achieve a very good targeting to poor families through the use of the Single Registry of poor families, and this has endowed Brazil with a very effective policy tool for combating poverty. It has also reduced poverty among children and youths, whose poverty rates are well above the overall average. The administrative structure of the programme is so effective that several state governments have decided to rely on the Single Registry to devise specific assistance programmes that go beyond federal benefits. For example, the state of Rio de Janeiro decided to top up Bolsa Familia benefits up to the level of the extreme poverty line, a policy that was adopted by the federal government for the whole country in 2012. All families with per capita incomes of BRL 70 per person are now receiving the amount of transfers necessary to lift their incomes to this level. This implies that, according to the BRL 70-definition, extreme poverty is almost eradicated by now, with the exception of a few households that are not covered by Bolsa Familia, e.g. perhaps because they have not yet been discovered by the Single Registry's active search policy.

Additional social programmes included in Brasil Sem Miseria deliver other social services to poor families according to their specific needs, such as early childhood education, care for elderly family members, training, assistance in finding employment or the provision of loans. By addressing specific bottlenecks of individual families, these programmes are meant to make the escape from poverty more sustainable and enable families to move away from dependence on transfer incomes.

Despite much progress, the integration of different social assistance and social protection programmes could be further enhanced. In addition to the federal government, state and municipal authorities also operate social assistance programmes, and sometimes these programmes overlap, or eligible recipients are not aware that they could apply for a certain kinds of assistance. A promising initiative is the roll-out of Centres of Reference for Social Assistance (CRAS) across municipalities with a high incidence of poverty. These centres deliver family-assistance services, and could become the main point of delivery of all assistance programmes, including federal programmes under Brasil sem Miseria and state and municipal programmes. At present, they are institutionally separated from Brasil sem Miseria, and a full integration could improve the awareness of households about the social assistance programmes for which they are eligible. Increasing this awareness could trigger additional strong demand for some of the assistance services offered and lead to bottlenecks in their delivery, such an integration would nonetheless enhance the transparency of social assistance policies and help identifying programmes or municipalities that should receive more resources. 


\section{Harnessing the tax system for redistribution objectives}

While transfers and the provision of public services appear to be the most efficient tools to reduce inequalities, the tax system can also contribute to distributional objectives, although there are some tradeoffs between making taxes more progressive and a potentially negative impact of such a change on economic efficiency. In fact, in many countries, the progressivity of taxation is a significant redistribution instrument, even though public expenditures typically account for three quarters of the overall redistributive impact in OECD countries (Joumard et al., 2012). In Brazil, however, reliance on the tax system for redistribution seems underexploited compared to other countries (Figure 20, also Immervoll et al., 2009).

Figure 20. Reduction of inequality through taxes and transfers

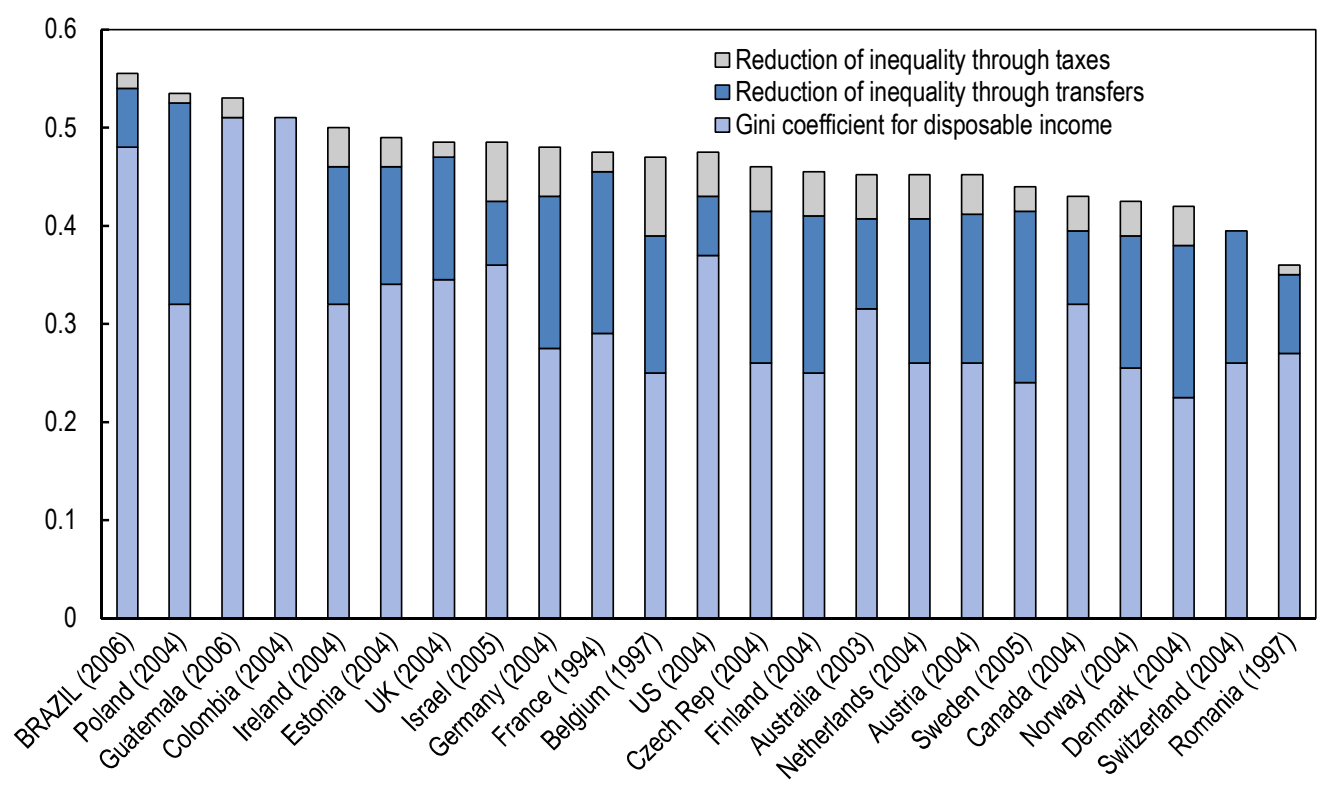

Note: The overall height of each column corresponds to the Gini coefficient for market income, i.e. before taxes and transfers.

Source: Luxembourg Income Study Database (LIS).

A closer look at the individual effects of taxes and transfers on inequality confirms that transfers are a key source of inequality reductions, and this applies both for cash-transfers and for in-kind transfers such as the imputed value of public health and education services. While the former reduce inequality by around $7.5 \%$, the latter decrease it by another $16 \%$. The tax system as a whole, i.e. taking both direct and indirect taxes together, actually increased the Gini coefficient in 2009, suggesting an overall regressive effect of taxes (Figure 21). This, however, masks stark differences between direct and indirect taxes. Direct taxes which account for around $45 \%$ of tax revenues - have a mildly progressive effect, reducing the Gini coefficient by around 1.5 percentage points, which corresponds to more than twice the average annual decline over the last decade. European countries achieve an average of 4 percentage points of inequality reduction through direct taxes (Atta-Darkua and Barnard, 2010). Taken together, transfers and direct taxes reduce inequality by around $10 \%$, which compares well by Latin American standards, but European countries manage to achieve a reduction of around one third through these instruments (Higgins and Pereira, 2013). Given that Brazil's level of taxes is not far away from European levels, this comparison suggests that more could be done to raise the distributional effect of direct taxes in Brazil. 
Figure 21. Effects of taxes and transfers on inequality

Gini coefficient, 2009

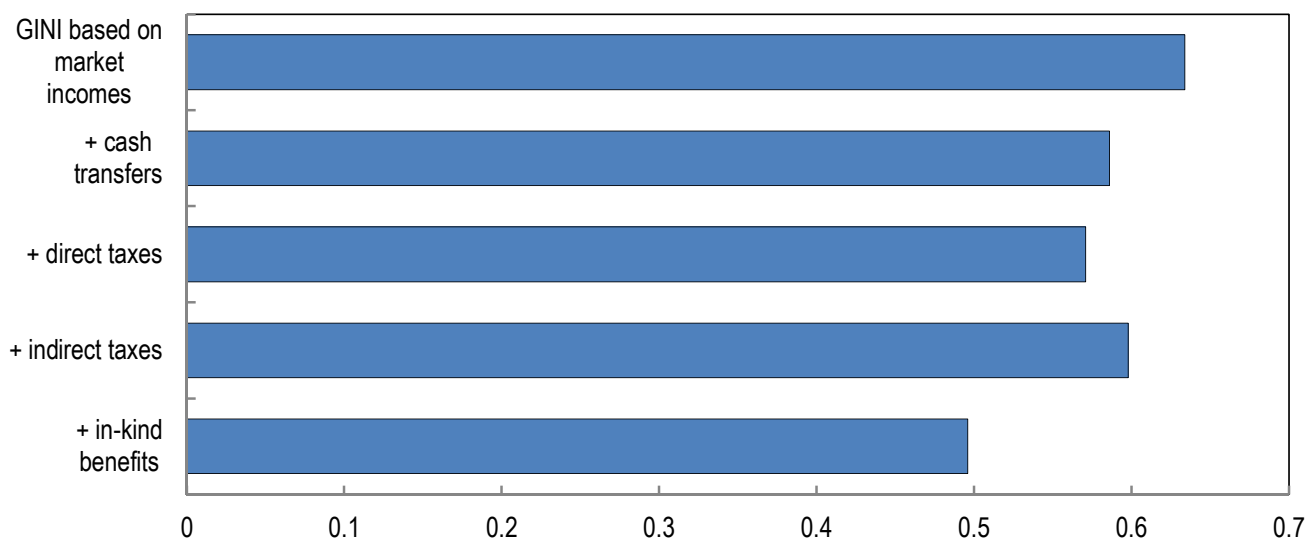

Source: IPEA (2011).

OECD estimates of the average tax wedge on labour income illustrate the low effective progressivity of personal income taxes and employee social security contributions in Brazil. For example, comparing the labour tax wedge for a single individual at $67 \%$ and $167 \%$ of the average wage, this wedge increases by only a tenth in Brazil, compared to an increase in the labour tax wedge by one quarter in the average OECD country (Gandullia et al., 2012). Social security contributions are currently capped at about twice the average wage, and this could be reconsidered to achieve more progressivity.

In contrast, indirect taxes - which account for 55\% of tax revenues in Brazil - are typically considered slightly regressive from the usual perspective of annual disposable income (although this may change when considering lifetime income instead). This is not unique to Brazil; in fact consumption taxes tend to have less favourable distribution effects than personal income taxes in most countries. In many cases, however, there are strong efficiency arguments for using consumption taxes nonetheless (Arnold et al., 2011), although in light of the fragmented and cascading nature of Brazil's indirect tax system and their large share of revenues - OECD countries raise about one third of revenues from consumption taxes it is doubtful to what extent this empirical result obtained on OECD countries carries over to Brazil. Simplifying the current system would be a first priority in the area of indirect taxes (see Chapter 1). If any revenue losses were to materialise in the process of a simplification, these could be replaced by a moderate increase of more progressive income taxes.

Lower rates on specific items consumed by low-income households have the potential to improve the distributional impact of consumption taxes, but they often do so at the expense of creating significant leakage. This applies also to the recent exemptions of food and toiletry items from federal indirect taxes, which have included items that are heavily consumed by high-income households. If the objective is to reach the poorest households, the tax revenues lost with these exemptions would be more effectively spent on transfers, such as Bolsa Familia, instead. 


\section{Box 1. Summary of recommendations:}

\section{Education}

- $\quad$ Scale up early childhood education, and improve upon its current quality level with more intense training and supervision of educators.

- $\quad$ Reduce the use of grade repetition and focus on early detection and tailored support with tutoring classes instead to reduce the number of drop-outs. Increase the subject-choice and integrate more vocational content in secondary education for students who are less academically-inclined.

- $\quad$ Continue expanding in-service teacher training and increase the number of teachers that participate.

- Extend the successful experience of some states, including São Paulo and Pernambuco, with performance-based teacher pay to a nationwide scale.

- Ensure full-day schooling nationwide and invest in school buildings where that is currently an obstacle to full-day schooling.

- Reinforce the Pronatec initiative with more resources to keep on expanding vocational training and apprenticeships.

\section{Health policies}

- Increase the funding for public health services and create more training places for doctors and nurses.

\section{Urban transport policies}

- $\quad$ Strengthen incentives and accountability for local governments to execute projects and withdraw unspent funds more rapidly.

- Reconsider local content requirements that drive up the costs of investment in urban transportation.

\section{Social transfers}

- $\quad$ Give higher priority to increasing Bolsa Familia and other policies under the Brasil Sem Miseria programme rather than pension expenditure. Sever the automatic link between increases in the minimum pension and the minimum wage. Introduce a general minimum retirement age and strengthen the disincentives for early retirement.

- To protect the purchasing power of the minimum wage while allowing a gradual reduction relative to the median wage, index annual minimum wage increases to the consumer price index for low-income households for some time.

- Allocate more resources to the conditional cash transfer programme Bolsa Familia and other social assistance programmes under the umbrella of Brasil sem Miseria.

- Work towards a full integration of social assistance programmes and delivery through local centres for social assistance (CRAS) to improve awareness about available programmes.

\section{Tax system}

- Increase the progressivity of direct taxes by reviewing the rate schedule, exemption thresholds and reconsidering the cap on social security contributions paid by employees.

- Remove the exemption of basic consumption items from federal indirect taxes and use these resources on more effective tools to improve income distribution, such as conditional cash transfers. 


\section{Bibliography}

Afonso, L., P. Pereda, F. Giambiagi and S. Franco (2011), "O Salario Mínimo como Instrumento de Combate a Pobreza Extrema: Estariam Esgotados os Efeitos?", Economia Aplicada, Vol. 15, No. 4, pp. 559-593.

Allwine, M., L. Lopez Calva and J. Rigolini, (2012), "Poverty, Inequality and Growth in Brazil", Background Paper for Poverty Dynamics in Brazil: Patterns Associated Factors and Policy Challenges, mimeo, World Bank.

Arnold, J., B. Brys, C. Heady, A. Johansson, C. Schwellnus and L. Vartia, (2011), “Tax Policy for Economic Recovery and Growth", Economic Journal, Vol. 121, Issue 550.

Atta-Darkua, V. and A. Barnard (2010), "Distributional effects of direct taxes and social transfers (cash benefits)", in: Income and living conditions in Europe, Atkinson, A., Marlier, E. (eds.), Eurostat, European Union Publications, Luxembourg.

Barros, R. et al., (2012), "Flexibilidade e Atractividade como Instrumentos para reduzir a Evasão e o Abandono no Ensino Medio", SAE/IETS policy note.

Barros, R., F. Ferreira, J. Vega and J. Chanduvi (2009), Measuring inequality of opportunities in Latin America and the Caribbean, World Bank, Palgrave Macmillan, Washington DC.

Barros, R., M. Carvalho, S. Franco and R. Mendonça (2010), "Markets, the state and the dynamics of inequality: Brazil's case study", in L. López-Calva and N. Lustig (eds) Declining inequality in Latin America: a decade of progress? Brookings Institution, Washington DC.

Bassi, M., M. Busso, S. Urzúa and J. Vargas (2012), Disconnected: Skills, Education and Employment in Latin America, Interamerican Development Bank, Washington DC.

Bianchi, R., L. López-Calva and J. Solomon (2012), "Evolution of Multidimensional Poverty at the National and State Level in Brazil", background paper for Poverty Dynamics in Brazil: patterns, associated factors and policy challenges, mimeo, Interamerican Development Bank, Washington DC.

Bruns, B. and C. Ferraz (forthcoming), "Paying Teachers to Perform in Brazil - the impact of Pernambuco's school bonus program”. World Bank, mimeo.

Early, D. et al., (2007), “Teachers' Education, Classroom Quality, and Young Children's Academic Skills: Results from Seven Studies of Preschool Programs", Child Development, Vol. 78, No. 2, pp. 558-580.

Evans, D. and K. Kosec (2012), Early Childhood Education: Making Programs Work For Brazil's Most Important Generation, World Bank, Washington DC.

Felicio, F., T. Menezes and A. Zoghbi (2012), "The Effects of Early Childhood Education On Literacy Scores Using Data From A New Brazilian Assessment Tool”, Estudos Econômicos, Vol. 42, No. 1, São Paulo.

Ferreira de Souza, P. (2013), "Poverty, Inequality and Social Policies in Brazil, 1995-2009”, International Policy Centre for Inclusive Growth, Working Paper No. 87, Brasilia, Brazil. 
Ferreira, F., J. Messina, J. Rigolini, L. López-Calva, M. Lugo and R. Vakis (2012), “Economic Mobility and the rise of the Latin American Middle Class", World Bank, Washington, DC.

Fruttero, A., A. Castaneda, L. Lopez-Calva and M. Lugo (2012), "Analyzing Poverty Dynamics in Brazil Using Synthetic Panels" background paper for Poverty Dynamics in Brazil: patterns, associated factors and policy challenges, mimeo, Interamerican Development Bank, Washington DC.

Gandullia, L., N. Iacobone and A.Thomas (2012), "Modelling the Tax Burden on Labour Income in Brazil, China, India, Indonesia and South Africa" OECD Taxation Working Papers, No. 14, OECD Publishing.

Glewwe, P., E. Hanushek, S. Humpage and R. Ravina (2011), "School Resources and Educational Outcomes in Developing Countries: a Review of the Literature from 1990 to 2010", NBER Working Papers, No. 17554, Cambridge, MA.

Gragnolati, M., O. Jorgensen, R. Rocha, and A. Fruttero (2011), Growing Old in an Older Brazil : Implications of Population Aging on Growth, Poverty, Public Finance and Service Delivery. World Bank, Washington DC.

Guimaraes, J. and B. Sampaio (2013), "Family Background and Students' Achievement on a University Entrance Exam" Education Economics, Vol. 21, No. 1, pp. 38-59.

Heckman, J. J. and D. V. Masterov (2007), "The Productivity Argument for Investing in Young Children." Working Paper, No. 5, Investing in Kids Working Group, Committee for Economic Development, Washington, D.C.

Higgins, S. and C. Pereira (2013), "The effects of Brazil's high taxation and social spending on the distribution of household income", Public Finance Review, forthcoming.

IBGE (2012), "Pesquisa Nacional por Amostra de Domicílios: Síntese de Indicadores 2011” in National Household Survey: Summary of Indicators, Brazilian Institute of Geography and Statistics (IBGE).

IMF (2012), Brazil: Selected Issues Paper, IMF Country Report No. 12/192, International Monetary Fund, Washington DC.

Immervoll, H., H. Levy, J. Nogueira, C. O'Donoghue and R. Bezerra de Siqueira (2009), "The Impact of Brazil's Tax-Benefit System on Inequality and Poverty", in: Klasen, S. and F. Nowak-Lehmann (eds.), Poverty, Inequality, and Policy in Latin America, MIT Press, Cambridge, MA, 2009.

IPEA (2011), "Equidade Fiscal no Brasil: Impactos distributivos da tributação e do gasto social", Comunicados do IPEA, No. 92, Instituto de Pesquisa Econômica Aplicada, Brasilia.

IPEA (2012), “A Década Inclusiva (2001-11), Desigualdade, Pobreza e Politicas de Renda" Comunicados do IPEA, No. 155, Instituto de Pesquisa Econômica Aplicada, Brasilia.

IPEA (2013), "Duas décadas de desigualdade e pobreza no Brasil medidas pela Pndas/IBGE". Comunicados do IPEA, No. 159, Instituto de Pesquisa Econômica Aplicada, Brasilia.

Joumard, I., M. Pisu and D. Bloch (2012), "Less income inequality and more growth - are they compatible?" in Part 3. Income Redistribution via Taxes and Transfers across OECD countries, OECD Economics Department Working Papers No. 926, OECD Publishing. 
López-Calva, L. and N. Lustig (2010), "Explaining the Decline in Inequality in Latin America : Technological Change, Educational Upgrading and Democracy", in Lopez Calva, L., Lustig, N. (eds) Declining Inequality in Latin America: a Decade of Progress? Brookings Institution Press, Baltimore.

López-Calva, L., N. Lustig and E. Ortiz (2011), "The Decline in Inequality in Latin America: How Much, Since When and Why?" Tulane University Working Paper, No. 1118, Tulane University, New Orleans.

Ministry of Education (2009), "Pesquisa Nacional de egressos dos Cursos Técnicos da Rede Federal de Educação Professional e Tecnológica (2003-2007)”, Brasilia.

Mesquita, R. A. and G. Neto (2010), "Regulatory Shortcomings of the Brazilian Social Security" Economic Analysis of Law Review, Vol. 1, No. 1, pp. 141-60.

Moss, P. (2000), “Training of Early Childhood Education and Care Staff' in International Journal of Education Research, Vol. 33, pp. 31-53.

Neri, M. (2011), A Nova Classe Media: o Lado Brilhante da Base da Pirâmide, FVG, Editora Saraiva.

Neri, M. (2012), As Razoes da Educação Professional: Olhar da Demanda, Rio de Janeiro, FGV/CPS.

OECD (2011a), Education at a Glance 2011: OECD indicators, OECD Publishing.

OECD (2011b), "When students repeat grades or are transferred out of school: What does it mean for education systems?" PISA in Focus, No. 6, OECD Publishing. www.oecd.org/pisa/pisainfocus/

OECD (2011c), Divided We Stand: Why inequality keeps rising? OECD Publishing.

OECD (2011d), Perspectives on Global Development 2012. Social Cohesion in a Shifting World, OECD Publishing.

OECD (2011e), Pensions at a Glance 2011: Retirement-income Systems in OECD and G-20 countries, OECD Publishing.

OECD (2012a), Education at a Glance 2012: OECD indicators, OECD Publishing.

OECD (2012b), Revenue Statistics in Latin America 1990-2010, OECD Publishing.

OECD (2013a), OECD Going for Growth 2013, OECD Publishing.

OECD (2013b), Investing in Youth: Brazil, forthcoming, OECD Publishing.

OECD (2013c), Education at a Glance 2013: OECD indicators, OECD Publishing.

OECD (2013d), Education Today 2013, OECD Publishing.

OECD (2013e), PISA 2012 Results in Focus: What 15-year-olds know and what they can do with what they know: Key results from PISA 2012, OECD Publishing.

Paim, J., Travassos, C., Almeida, C., Bahia, L. and Macinko, J. (2011), "The Brazilian health system: history, advances and challenges", Lancet, Vol. 377, pp. 1778-1797. 
PNAD (2011), "National Household Sample Survey-Pesquisa Nacional por Amostra de Domicílios 201 1" Brazilian Institute of Geography and Statistics (IBGE).

SAE (2012), Vozes da Classe Media: Desigualdade, heterogeneidade e diversidade, Caderno 2, Secretaria de Assuntos Estratégicos, Brasilia.

Schwartzman, S. (2010), "Benchmarking Secondary Education in Brazil”, IETS Working Paper, Brasilia.

Soares, S. (2012), "Bolsa Familia, its design, its impacts and possibilities for the future", IPEA Working Papers, No. 89, Institute for Applied Economic Research (IPEA), Brasilia.

United Nations (2012), Addressing Inequalities: The Heart Of The Post-2015 Agenda And The Future We Want For All, UN System Task Team on the Post-2015 UN Development Agenda, United Nations, New York, NY.

World Bank (2012), Achieving World Class Education in Brazil: The Next Agenda. World Bank, Washington, DC.

World Bank (2013), "World Development Indicators", World Bank, Washington, D.C. Available online at http://data.worldbank.org/indicator/all. 
ECO/WKP(2014)1

\section{WORKING PAPERS}

The full series of Economics Department Working Papers can be consulted at www.oecd.org/eco/workingpapers/

1104. New indicators of competition law and policy in 2013 for OECD and non-OECD countries (December 2013) by Enrico Alemani, Caroline Klein, Isabell Koske, Cristiana Vitale and Isabelle Wanner

1103. The effect of government debt, external debt and their interaction on OECD interest rates (December 2013) by David Turner and Francesca Spinelli

1102. The state of the banking sector in Europe (December 2013) by Dirk Schoenmaker and Toon Peek

1101. Getting Irish youth on the job track

(December 2013) by Alberto González Pandiella

1100. New econometric estimates of long-term growth effects of different areas of public spending (December 2013) by Omar Barbiero and Boris Cournède

1099. Cross-country spillovers from fiscal consolidations

(December 2013) by Antoine Goujard

1098. Informal employment in Russia: definitions, incidence, determinants and labour market segmentation

(December 2013) by Hartmut Lehmann and Anzelika Zaiceva

1097. Capacity needs in the automobile industry in the short- to medium run

(November 2013) by Caroline Klein and Isabell Koske

1096. Environmental policies and productivity growth - a critical review of empirical findings

(November 2013) by Tomasz Koźluk and Vera Zipperer

1095. Green growth challenges and the need for an energy reform in Mexico

(November 2013) by Carla Valdivia de Richter

1094. From bricks to brains: increasing the contribution of knowledge-based capital to growth in Ireland

(November 2013) by David Haugh

1093. China's march to prosperity: reforms to avoid the middle-income trap

(November 2013) by Vincent Koen, Richard Herd and Sam Hill

1092. Multi factor productivity with natural capital

(November 2013) by Nicola Brandt, Paul Schreyer and Vera Zipperer

1091. Growth-promoting policies and macroeconomic stability

(November 2013) by Douglas Sutherland and Peter Hoeller

1090. Policies for inclusive urbanisation in China

(October 2013) by Vincent Koen, Richard Herd, Xiao Wang and Thomas Chalaux 
1089. Fiscal devaluation - can it help to boost competitiveness?

(October 2013) by Isabell Koske

1088. How to achieve growth- and equity-friendly fiscal consolidation? A proposed methodology for instrument choice with an illustrative application to OECD countries

(October 2013) by Boris Cournède, Antoine Goujard and Álvaro Pina

1087. Improving school-to-work transition in New Zealand

(September 2013) by Alexandra Bibbee

1086. The agri-food situation and policies in Switzerland

(September 2013) by Peter Jarrett and Charlotte Moeser

1085. Japan's challenging debt dynamics

(August 2013) by Yvan Guillemette and Jan Strasky

1084. Transitions in and out of unemployment among young people in the Irish recession

(August 2013) by Elish Kelly, Seamus McGuinness, Philip O'Connell, David Haugh and Alberto González Pandiella

1083. Is there convergence of Russia's regions? Exploring the empirical evidence: 1995-2010

(August 2013) by Hartmut Lehmann and Maria Giulia Silvagni

1082. The benefits and costs of highly expansionary monetary policy

(August 2013) by Łukasz Rawdanowicz, Romain Bouis and Shingo Watanabe

1081. The effectiveness of monetary policy since the onset of the financial crisis

(August 2013) by Romain Bouis, Łukasz Rawdanowicz, Jean-Paul Renne, Shingo Watanabe and Ane Kathrine Christensen

1080. Responding to key well-being challenges in Austria

(August 2013) by Rauf Gönenç, Oliver Röhn, Christian Beer and Andreas Wörgötter

1079. Austria's well-being goes beyond GDP

(August 2013) by Oliver Röhn, Rauf Gönenç, Christian Beer and Romina Boarini

1078. Improving fiscal federal relations for a stronger Mexico

(August 2013) by Aida Caldera Sánchez

1077. Deleveraging: challenges, progress and policies

(August 2013) by Romain Bouis, Ane Kathrine Christensen and Boris Cournède

1076. Policies to support sustainable long-term growth in New Zealand

(July 2013) by Calista Cheung

1075. Do structural policies affect macroeconomic stability?

(July 2013) by Volker Ziemann

1074. A simple fiscal stress testing model - case studies of Austrian, Czech and German economies (July 2013) by Ondra Kamenik, Zdenek Tuma, David Vavra and Zuzana Smidova. 